Georgetown University Law Center

Scholarship @ GEORGETOWN LAW

2015

\title{
The Evolution and Vitality of Merger Presumptions: A Decision- Theoretic Approach
}

Steven C. Salop

Georgetown University Law Center, salop@law.georgetown.edu

This paper can be downloaded free of charge from:

https://scholarship.law.georgetown.edu/facpub/1304

http://ssrn.com/abstract=2375354

This open-access article is brought to you by the Georgetown Law Library. Posted with permission of the author. Follow this and additional works at: https://scholarship.law.georgetown.edu/facpub

Part of the Antitrust and Trade Regulation Commons, and the Law and Economics Commons 


\title{
THE EVOLUTION AND VITALITY OF MERGER PRESUMPTIONS: A DECISION-THEORETIC APPROACH
}

\author{
Steven C. SAlop*
}

\begin{abstract}
[A] merger which produces a firm controlling an undue percentage share of the relevant market, and results in a significant increase in the concentration of firms in that market is so inherently likely to lessen competition substantially that it must be enjoined in the absence of evidence clearly showing that the merger is not likely to have such anticompetitive effects.
\end{abstract}

Philadelphia National Bank ${ }^{1}$

I have come to celebrate Philadelphia National Bank (PNB), not to bury it. ${ }^{2}$ As an analytic matter, $P N B$ involved the application of decision theory to antitrust. It formulated what we would now call a "quick look" type of decision process of using a preliminary screen to create a rebuttable presumption that certain mergers are anticompetitive. In $P N B$, that presumption was applied to proposed mergers uniting firms with high combined market shares in highly concentrated markets. This presumption, and its associated high burden of production placed on rebuttal evidence, was based on an economic view widely accepted at the time regarding the likely anticompetitive impact of such mergers. The economic presumption has become weaker over time, and that has led to the rebuttable presumption also becoming weaker. However,

* Professor of Economics and Law, Georgetown University Law Center; Senior Consultant, Charles River Associates. An earlier version of this article was presented at the Conference on the Fiftieth Anniversary of United States v. Philadelphia National Bank, held at New York University School of Law (Nov. 15, 2013). I have benefited greatly from the treatment of these issues in Andrew I. Gavil, Burden of Proof in U.S. Antitrust Law, in 1 ABA Section of AnTItrust Law, Issues in Competition Law and Policy 125 (W. Dale Collins ed., 2008), and helpful conversations and comments from Jonathan Baker, Dennis Carlton, Malcolm Coate, Andrew Gavil, Douglas Ginsburg, Thomas Krattenmaker, John Kwoka, Serge Moresi, Paul Rothstein, Carl Shapiro, Sean Sullivan, Mariano Tappata, Lawrence White, Robert Willig, and Joshua Wright.

${ }^{1}$ United States v. Phila. Nat'l Bank, 374 U.S. 321, 363 (1963).

${ }^{2}$ Banking deregulation, mergers, and the financial meltdown led to the disappearance of Philadelphia National Bank. Philadelphia National Bank became CoreStates, which then was purchased by First Union in 1998, which purchased and took the name of Wachovia in 2001, which in turn was rescued by Wells Fargo in the 2008 financial meltdown.

80 Antitrust Law Journal No. 2 (2015). Copyright 2015 American Bar Association. Reproduced by permission. All rights reserved. This information or any portion thereof may not be copied or disseminated in any form or by any means or downloaded or stored in an electronic database or retrieval system without the express written consent of the American Bar Association. 
the basic "quick look" structure remains central in the law. The antitrust agencies also have adopted enforcement presumptions that reflect the economic evidence and the way in which the courts have applied the $P N B$ rebuttable presumption. Looking forward, as economic analysis has advanced, alternative measures have been developed that can supplement or even eventually replace concentration as a basis for anticompetitive legal and enforcement presumptions. Thus, merger law can continue to evolve, while retaining the vitality of $P N B$ 's basic decision-theoretic approach.

Justice Brennan's opinion in $P N B$ built on the legislative history of Section 7 of the Clayton Act and Brown Shoe ${ }^{3}$ to create a quick look rule of reason process for merger analysis. ${ }^{4}$ If the merger leads to a combined firm with a sufficiently large market share in a sufficiently concentrated market, then the merger is presumed anticompetitive as a matter of law. The merging parties can rebut this anticompetitive evidentiary presumption with evidence "clearly showing" that the merger is unlikely to cause competitive harm. ${ }^{5}$ In the $P N B$ case, the Supreme Court rejected certain specific rebuttals involving the vigor of remaining competition, efficiencies, and social benefits to the Philadelphia economy. ${ }^{6}$ The Court also limited the efficiencies rebuttal as a matter of law solely to merger-specific competitive benefits within the relevant market. ${ }^{7}$

Over the past 50 years, the courts have elucidated and expanded the rebuttal factors and adjusted the burden of production to rebut the evidentiary presumption placed on the merging firms. Today, the rebuttal factors include ease of entry and other supply responses (e.g., repositioning), lack of premerger competition, continued intense post-merger market competition, and merger-specific efficiencies. The Department of Justice introduced "quasisafe harbor" (i.e., not-anticompetitive) enforcement presumptions into the 1982 Merger Guidelines, presumptions that the agencies have updated over time. ${ }^{8}$ The "clear showing" rebuttal standard of proof has been eased by the

\footnotetext{
${ }^{3}$ Brown Shoe Co. v. United States, 370 U.S. 294 (1962).

${ }^{4}$ The $P N B$ opinion apparently was drafted by Judge Richard Posner while he was clerking for Justice Brennan. Posner reported that his approach was inspired by the Derek Bok article cited in the opinion, which he had cite-checked as a journal editor while attending law school. Philadelphia National Bank at 50: An Interview with Judge Richard Posner, supra this issue, 80 Antitrust L.J. 205, 205-06 (2015).

${ }^{5}$ Philadelphia National Bank, 374 U.S. at 363.

${ }^{6} \mathrm{Id}$. at $369-71$.

${ }^{7} I d$. at 370 (requiring defendants to prove that they could not expand "by opening new offices rather than acquiring existing ones").

${ }^{8}$ U.S. Dep't of Justice, 1982 Merger Guidelines § 3.A.1 [hereinafter 1982 Merger Guidelines], available at www.justice.gov/atr/hmerger/11248.pdf; U.S. Dep't of Justice \& Fed. Trade Comm'n, Horizontal Merger Guidelines $§ 5.3$ (2010) [hereinafter 2010 Merger Guidelines], available at ftc.gov/os/2010/08/100819hmg.pdf.
} 
courts, and the defendants' burden of production now involves a sliding scale. ${ }^{9}$ However, the basic analytic framework remains applicable.

This article reviews the formulation and evolution of the $P N B$ rebuttable presumption through the lens of economic decision theory, including the role played by advances in economic analysis. The article also sketches out the prospects for further evolution and suggest a number of non-market share structural factors that might form the basis of rebuttable evidentiary presumptions. The article also examines the potential for conflicting evidence and how such conflicts might be resolved.

\section{THE EVOLUTION OF THE $P N B$ REBUTTABLE PRESUMPTION}

Trenton Potteries ${ }^{10}$ and Socony-Vacuum ${ }^{11}$ formulated the seminal standard of per se illegality for price fixing. As explained by Professor Thomas Krattenmaker, those per se standards of illegality rejected certain defenses, ${ }^{12}$ including the reasonableness of the price that was fixed, lack of market power, and any alleged benefits from the elimination of ruinous competition. ${ }^{13}$ In decision-theory terms, the per se rule represents a non-rebuttable (i.e., conclusive) presumption of anticompetitive effects for price fixing. The Supreme Court's 1958 opinion in Northern Pacific presents this classic statement:

[T]here are certain agreements or practices which because of their pernicious effect on competition and lack of any redeeming virtue are conclusively presumed to be unreasonable and therefore illegal without elaborate inquiry as to the precise harm they have caused or the business excuse for their use. This principle of per se unreasonableness not only makes the type of restraints which are proscribed by the Sherman Act more certain to the benefit of everyone concerned, but it also avoids the necessity for an incredibly complicated and prolonged economic investigation into the entire history of the industry involved, as well as related industries, in an effort to determine at large whether a particular restraint has been unreasonable-an inquiry so often wholly fruitless when undertaken. ${ }^{14}$

This standard avoids the delays and other costs of a rule of reason analysis, the potential for errors that such analysis may entail, and the potential for under-deterrence caused by such errors. However, the truncated analysis creates its own potential for false positives.

\footnotetext{
92010 Merger Guidelines, supra note 8, § 10; United States v. Baker Hughes Inc., 908 F.2d 981, 991 (D.C. Cir. 1990) ("The more compelling the prima facie case, the more evidence the defendant must present to rebut it successfully.").

${ }^{10}$ United States v. Trenton Potteries Co., 273 U.S. 392 (1927).

${ }^{11}$ United States v. Socony-Vacuum Oil Co., Inc., 310 U.S. 150 (1940).

${ }^{12}$ Thomas G. Krattenmaker, Per Se Violations in Antitrust Law: Confusing Offenses with Defenses, 77 GEO. L.J. 165, 178 (1988).

${ }^{13}$ Id. 173-74.

${ }^{14}$ N. Pac. Ry. Co. v. United States, 356 U.S. 1, 5 (1958) (emphasis added).
} 


\section{A. The PNB "Quick Look" Standard}

Northern Pacific's formulation of the per se rule forms the decision-theory foundation for $P N B$. $P N B$, which was decided five years later, followed Brown Shoe in recognizing that the determination of the competitive effects of a proposed merger is a matter of "probabilities, not certainties." ${ }^{15}$ PNB suggests that the requirement to predict the transaction's likely competitive effects follows from the statute's objective to "arrest anticompetitive tendencies in their "incipiency." The opinion also recognizes that the required economic analysis is difficult, and a simple test is needed for efficient administration. As stated in the opinion:

[W] come to the ultimate question under $\S 7$ : whether the effect of the merger "may be substantially to lessen competition" in the relevant market. Clearly, this is not the kind of question which is susceptible of a ready and precise answer in most cases. It requires not merely an appraisal of the immediate impact of the merger upon competition, but a prediction of its impact upon competitive conditions in the future; this is what is meant when it is said that the amended $\S 7$ was intended to arrest anticompetitive tendencies in their "incipiency." Such a prediction is sound only if it is based upon a firm understanding of the structure of the relevant market; yet the relevant economic data are both complex and elusive. ... And so in any case in which it is possible, without doing violence to the congressional objective embodied in § 7, to simplify the test of illegality, the courts ought to do so in the interest of sound and practical judicial administration. ${ }^{16}$

Unlike the rule for tying set out in Northern Pacific, PNB does not "conclusively presume" that all mergers are anticompetitive. Mergers combine production facilities, which leads to plausible efficiency benefits. The anticompetitive presumption applies only to certain mergers that are "inherently suspect." 17 Moreover, the presumption is rebuttable. As the Court famously stated:

Specifically, we think that a merger which produces a firm controlling an undue percentage share of the relevant market, and results in a significant increase in the concentration of firms in that market is so inherently likely to lessen competition substantially that it must be enjoined in the absence of evidence clearly showing that the merger is not likely to have such anticompetitive effects. ${ }^{18}$

The rebuttable presumption placed a high burden of proof on the defendant by requiring the production of evidence "clearly showing" lack of harm. ${ }^{19} \mathrm{Be}-$

\footnotetext{
${ }^{15}$ Brown Shoe Co. v. United States, 370 U.S. 294, 323 (1962).

${ }^{16}$ United States v. Phila. Nat'l Bank, 374 U.S. 321, 362 (1963) (citations omitted).

${ }^{17} I d$. at 363 .

${ }^{18} \mathrm{Id}$.

${ }^{19}$ The $P N B$ formulation of the "clear showing" requirement appears to raise the burden of persuasion on the defendant, not just the burden of production. This distinction is discussed in more detail below.
} 
cause of Von' $s^{20}$ and some other post- $P N B$ cases, the concentration levels necessary to trigger the presumption have been characterized as extraordinarily low. But it is noteworthy that $P N B$ itself does not fit that characterization. As shown in Table 1 below, the post-merger Herfindahl-Hirschman Indices (HHIs) in $P N B$ likely were in the 2000-2100 range. The combined market share of the merging firms was 34-36 percent, depending on the measure of output, and the merger increased the HHI by approximately 600 points. ${ }^{21}$ Thus, the post-merger markets would have been in the "highly concentrated" region of the 1982-1992 Merger Guidelines, where they would have been treated as presumptively anticompetitive. ${ }^{22}$

TABLE 1

PHILADELPHIA NATIONAL BANK MARKET SHARES AND HHIS

\begin{tabular}{|c|c|c|c|c|}
\hline & \multicolumn{2}{|c|}{ Loans } & \multicolumn{2}{|c|}{ Deposits } \\
\hline & Market Share & $\underline{\text { HHI }}$ & Market Share & $\underline{\text { HHI }}$ \\
\hline PNB & $19.8 \%$ & 392 & $21.3 \%$ & 454 \\
\hline Girard & $14.6 \%$ & 213 & $14.5 \%$ & 210 \\
\hline First Pennsylvania & $23.8 \%$ & 566 & $22.1 \%$ & 488 \\
\hline \#4 & $10.2 \%$ & 104 & $9.9 \%$ & 98 \\
\hline \#5 & $9.0 \%$ & 81 & $9.3 \%$ & 86 \\
\hline \multirow{5}{*}{ Other* } & $22.6 \%$ & 102 & $22.9 \%$ & 105 \\
\hline & $100 \%$ & & $100 \%$ & \\
\hline & $\boldsymbol{H} \boldsymbol{H I}^{p r e}$ & 1459 & $\boldsymbol{H} \boldsymbol{H I}^{p r e}$ & 1442 \\
\hline & $\Delta H H I$ & 578 & $\Delta H H I$ & 618 \\
\hline & $\boldsymbol{H} \boldsymbol{H I}^{p o s t}$ & 2037 & $H H^{p o s t}$ & 2059 \\
\hline
\end{tabular}

* "Other" is treated as five equal-sized firms for HHI calculations.

The $P N B$ standard rule can be characterized as a type of "quick look" rule of reason approach. If the market shares and concentration levels are sufficiently high, the merger is considered to raise significant competitive concerns, and the burden of production shifts to the merging parties to rebut

\footnotetext{
${ }^{20}$ United States v. Von's Grocery Co., 384 U.S. 270 (1966).

${ }^{21}$ The district court opinion only provides the shares for the top five firms. United States v. Phila. Nat'l Bank, 201 F. Supp. 348, 366 (1962). To calculate the HHIs, I assumed the remaining firms had HHI contributions equivalent to five equal-sized firms.

${ }^{22}$ See U.S. Dep't of Justice \& Fed. Trade Comm'n, Horizontal Merger Guidelines § 1.51 (1992, rev. 1997) [hereinafter 1992 Merger Guidelines], available at www.justice.gov/atr/public/ guidelines/hmg.pdf. The 2010 Merger Guidelines have now raised the concentration level required for applying an anticompetitive enforcement presumption up to a post-merger HHI level of 2500 and an increase in the HHI of 200. 2010 Merger Guidelines, supra note 8, § 5.3. Thus, the $P N B$ post-merger market today would fall into the "moderately concentrated" range. But the 600 point increase still would be said to raise "significant" concerns.
} 
the presumption by demonstrating that the transaction is not likely to reduce competition. ${ }^{23}$

$P N B$ is not the first use of such a quick look standard. Judge Hand formulated a quick look standard in Alcoa, stating that "if it was an excuse, that 'Alcoa' had not abused its power, it lay upon 'Alcoa' to prove that it had not." 24 Indeed, as a purely analytic matter, the "quick look" approach to Section 1 horizontal price-setting agreements subsequently developed in $B M I,{ }^{25} N C A A,{ }^{26}$ and later cases also flow directly from Alcoa and $P N B \cdot{ }^{27}$ Of course, there is one key difference between the quick look for potential horizontal price fixing and the $P N B$ approach to horizontal mergers. In horizontal price fixing, successful rebuttal triggers a rule of reason analysis, which can be said to involve a further burden-shifting process. In $P N B$, successful rebuttal leads to the merger being permitted.

\section{B. BAKER Hughes AND HeINZ}

While rebuttable in principle, the courts immediately after $P N B$ interpreted the "clear showing" rebuttal standard to establish a very high bar for demonstrating that presumptively unlawful mergers would not reduce competition. ${ }^{28}$ In the 50 years since $P N B$, however, competitive effects analysis has evolved in economics, the agencies, and the courts. As a result, the anticompetitive presumption has become both harder to satisfy and easier to rebut.

\footnotetext{
${ }^{23}$ Sean Sullivan suggests that the structural presumption is better viewed as a "substantive inference" based on the evidence, not a classical legal presumption. Sean P. Sullivan, What Structural Presumption? Reuniting Evidence and Economics on the Role of Market Concentration in Horizontal Merger Analysis (unpublished manuscript) (Aug. 1, 2015), available at ssully.com/attachments/papers/wsp_2015.pdf.

${ }^{24}$ United States v. Aluminum Co. of Am., 148 F.2d 416, 427 (2d Cir. 1945) (Alcoa). The application of the quick look approach to Section 2 also was adopted in Aspen and Kodak. See Aspen Skiing Co. v. Aspen Highlands Skiing Corp., 472 U.S. 585 (1985); Eastman Kodak Co. v. Image Technical Servs., Inc., 504 U.S. 451 (1992). For further discussion, see Jonathan B. Baker, Promoting Innovation Competition Through the Aspen/Kodak Rule, 7 GEO. MAson L. Rev. 495 (1999).

${ }^{25}$ Broad. Music, Inc. v. CBS, Inc., 441 U.S. 1 (1979).

${ }^{26}$ NCAA v. Bd. of Regents of Univ. of Okla., 468 U.S. 85 (1984).

${ }^{27}$ For example, consider this description of the quick look rule of reason approach from Brown University: "[C]ourts sometimes apply what amounts to an abbreviated or " "quick look" " rule of reason analysis. The abbreviated rule of reason is an intermediate standard. It applies in cases where per se condemnation is inappropriate, but where "no elaborate industry analysis is required to demonstrate the anticompetitive character" of an inherently suspect restraint." United States v. Brown Univ., 5 F.3d 658, 669 (3d Cir. 1993).

${ }^{28}$ As famously stated by Justice Stewart in his dissent in Von's, "The sole consistency that I can find is that, in litigation under $\S 7$, the Government always wins." United States v. Von's Grocery Co., 384 U.S. 270, 301 (1966) (Potter, J., dissenting).
} 
The 1990 Baker Hughes ${ }^{29}$ opinion by the D.C. Circuit panel (which included future Justices Ginsburg and Thomas) continued to recognize the predictive nature of the analytic process, explaining that "Section 7 involves probabilities, not certainties or possibilities." ${ }^{30}$ However, the court rejected the "clear showing" evidentiary standard, stating this formulation "overstates the defendant's burden" to rebut a prima facie case based on high market share and concentration. ${ }^{31}$ According to the court, in post- $P N B$ merger cases, the Supreme Court "lightened the evidentiary burden" on the defendant. ${ }^{32}$ The court formally replaced $P N B$ 's "clear showing" standard with one of simply having to "show" that "the prima facie case inaccurately predicts the relevant transaction's probable effect on future competition." ${ }^{33}$

The opinion thus permits and even invites lower courts to permit a wideranging competitive effects analysis. ${ }^{34}$ It retained the presumption of harm, but weakened it. In addition, Baker Hughes made clear that the government, not the merging firms, bears the ultimate burden of proof. ${ }^{35} \mathrm{~A}$ subsequent D.C. Circuit panel in Heinz also extended this view even for a 3-to-2 merger. ${ }^{36}$ The panel accepted that a successful rebuttal requires evidence showing that the market share statistics provide "an inaccurate account of the [merger's] probable effects on competition," and recognized the possibility that an efficiencies defense could prevail. ${ }^{37}$

However, both Baker Hughes and Heinz rejected the view that concentration is irrelevant. Baker Hughes explicitly embraced a sliding scale approach, whereby " $[t]$ he more compelling the prima facie case, the more evidence the defendant must present to rebut it successfully." 38 This was followed and emphasized in Heinz. After finding high concentration in this 3-to-2 merger, the Heinz court concluded that the high concentration "creates, by a wide margin, a presumption that the merger will lessen competition." ${ }^{39}$ After finding that there also were barriers to entry, the court concluded that "no court has ever

\footnotetext{
${ }^{29}$ United States v. Baker Hughes Inc., 908 F.2d 981 (D.C. Cir. 1990).

${ }^{30} \mathrm{Id}$. at 984 (italics omitted).

${ }^{31} I d$. at 989.

${ }^{32} \mathrm{Id}$. at 991.

${ }^{33} I d$. As stated, this appears to be a reduction in the burden of proof. However, whether there is a meaningful analytical difference between a lowering of the burden of proof and the lowering of the burden of production is not clear, as discussed below.

${ }^{34}$ As stated by the court, market concentration "simply provides a convenient starting point for a broader inquiry into future competitiveness." See id. at 984 . This characterization is literally inaccurate in that concentration is the sole factor that triggers the presumption.

${ }^{35}$ Baker Hughes, 908 F.2d at 982 . The ultimate burden of proof merges with the burden of persuasion in the final instance. Id.

${ }^{36}$ FTC v. H.J. Heinz Co., 246 F.3d 708, 715 (D.C. Cir. 2001).

${ }^{37} I d$. (citations omitted).

${ }^{38}$ Baker Hughes, 908 F.2d at 991.

${ }^{39}$ Heinz, 246 F.3d at 716 (emphasis added).
} 
approved a merger to duopoly under similar circumstances." ${ }^{40}$ The Heinz court went further by requiring that a rebuttal premised on the presence of "structural market barriers to collusion" in a merger to duopoly also must establish that the barriers make tacit collusion more difficult to achieve or maintain than in other industries. ${ }^{41}$ In this sense, the court made it clear that the burden of production on the merging firms increases when post-merger concentration is higher. ${ }^{42}$

\section{The Role of Economic Analysis in the Evolution}

This evolution to a weaker presumption based on market shares and concentration is consistent with and was likely caused by the parallel evolution of economic analysis. ${ }^{43}$ The inferences drawn from the original empirical economic studies asserting that profits were positively correlated with concentration were shown to be problematical. ${ }^{44}$ Greater experience with merger investigations and enforcement also resulted in the antitrust agencies more frequently concluding that transactions that increased concentration do not likely result in reduction in competition, particularly in a differentiated product market.

Nonetheless, economic theory and subsequent empirical evidence do not suggest ignoring market shares and concentration in merger analysis. First, various theories of oligopoly conduct - both static and dynamic models of firm interaction-are consistent with the view that competition with fewer significant firms on average is associated with higher prices. In general, the smaller the number of firms, the more likely the firms will be able to reach a mutually satisfactory outcome at a higher-than-competitive price. Unilateral price increases or output restraints also are more likely to be profitable when the merged firms have higher market shares, ceteris paribus. Accordingly, a horizontal merger reducing the number of rivals from four to three, or three to two, would be more likely to raise competitive concerns than one reducing the number from ten to nine, ceteris paribus.

\footnotetext{
${ }^{40} \mathrm{Id}$. at 717.

${ }^{41} I d$. at 725 (finding "structural market barriers to collusion" did not rebut the anticompetitive presumption because barriers alleged were not "unique to the baby food industry").

${ }^{42}$ The more substantial weight accorded concentration in Heinz relative to Baker Hughes also may have derived from the D.C. Circuit's skepticism about the efficiency defenses proffered by the merging firms.

${ }^{43}$ For an earlier discussion of these points, see Jonathan B. Baker \& Steven C. Salop, Should Concentration Be Dropped from the Merger Guidelines?, in ABA Section of ANTITRust Law, Perspectives on Fundamental Antitrust Theory 348 (2001), reprinted in 33 UWLA L. Rev. 3 (2001).

${ }^{44}$ The earlier studies did not control for all the relevant factors that could affect prices and profit margins. See, e.g., Industrial Concentration: The New Learning 162-245 (Harvey J. Goldschmid et al. eds., 1974) (chapter compiling essays on concentration and profit).
} 
Second, there is considerable empirical evidence consistent with a positive but weak relationship between market concentration and price. Few economists today would defend a presumption based upon a claimed relationship between market concentration and industry economic profits. But most leading economists would agree that the studies do show that concentration is positively related to price. For example, in summarizing a number of econometric studies in 1989, Richard Schmalensee concluded that "[i]n crosssection comparisons involving markets in the same industry, seller concentration is positively related to the level of price." ${ }^{45}$ In a 2004 presentation to the FTC, Craig Newmark quoted 24 articles whose authors accepted the validity and relevance of cross-section econometric studies showing that higher concentration leads to higher prices in those local areas. ${ }^{46}$

The evidence does not suggest a conclusive anticompetitive presumption. The studies finding a relationship between concentration and price are imperfect. They do not always define markets properly or adequately account for the reverse effect of price on concentration, for example. And it certainly is true that collusion does not occur in every highly concentrated market while collusion sometimes does succeed in markets that are not so highly concen-

\footnotetext{
${ }^{45}$ Richard Schmalensee, Inter-Industry Studies of Structure and Performance, in 2 HANDBOOK OF Industrial ORganization 951, 988 (Richard Schmalensee \& Robert Willig eds., 1989) (Stylized Fact 5.1); see also Concentration AND PRice (Leonard W. Weiss ed., 1989) (collection of studies); Timothy F. Bresnahan \& Valerie Y. Suslow, Oligopoly Pricing with Capacity Constraints, Annales D'Economie et de Statistique, July-Dec. 1989, at 267.

${ }^{46}$ Craig M. Newmark, Price-Concentration Studies: There You Go Again (Feb. 14, 2004), available at papers.ssrn.com/sol3/papers.cfm?abstract_id=503522/. Professor Newmark criticized those studies for three reasons, none of which appears valid. First, he argued that non-price competition could have caused the higher prices. His causation argument is implausible, however, because he fails to explain why the non-price competition would be stronger in more concentrated local markets. Second, he argued that higher costs in more concentrated markets could have caused the higher prices and suggests that this might have been the case in Staples. FTC v. Staples, Inc., 970 F. Supp. 1066 (D.D.C. 1997). However, this argument is inconsistent with the documentary evidence in the Staples case, which did not indicate that any important unobservable cost variables affected pricing, except in one city. Jonathan B. Baker, Econometric Analysis in FTC v. Staples, 18 J. Pub. Pol'y \& Mктg. 11, 15 (1999). It is also inconsistent with the pattern of regional expansion observed among the firms in that case: when one chain served a city, that city was typically near one of its existing or planned regional distribution centers and not near a rival's distribution center. See id. at 13 (The merging office supply superstore chains had "aggressive premerger expansion plans."). Third, Professor Newmark made a more general claim that failure to account for the endogeneity of entry would bias empirical studies toward finding a relationship between higher prices and higher market concentration when one does not exist. However, this claim is contradicted by the empirical literature demonstrating that the bias goes in the opposite direction, tending to understate the strength of a price-concentration relationship, including in Staples. Baker, supra, at 17; William N. Evans, Luke M. Froeb \& Gregory J. Werden, Endogeneity in the Concentration Price Relationship: Causes, Consequences, and Cures, 41 J. Indus. Econ. 431 (1993); Mark D. Manuszak \& Charles C. Moul, Prices and Endogenous Market Structure in Office Supply Superstores, 56 J. Indus. Econ. 94 (2008); Vishal Singh \& Ting Zhu, Pricing and Market Concentration in Oligopoly Markets, 27 MARKETING SCI. 1020 (2008).
} 
trated. Economic theory and empirical evidence make it clear that other industry-specific and market-specific factors beyond concentration are also important in determining the competitive effects of mergers. While a presumption based on market shares and concentration has an economic basis, other evidence also is relevant for determining the intensity of competition, including entry conditions, the similarities or differences among firms and their products, the size of buyers, and others. Contemporary economic learning suggests that concentration be considered when undertaking competitive effects analysis - in conjunction with other factors suggested by the competitive effects theory-but not treated as the sole determinant of post-merger pricing. ${ }^{47}$ In short, the case law, empirical evidence, and economic theory support a moderate rebuttable presumption that a merger uniting firms with high combined shares in a highly concentrated market is likely anticompetitive.

\section{Current Agency Enforcement Presumptions and Practice}

This weaker $P N B$ presumption is reflected in the way the enforcement agencies currently use concentration in their merger practice. The Merger Guidelines contain enforcement presumptions based on concentration. Most notably, mergers that create highly concentrated markets and significantly increase concentration are considered presumptively anticompetitive. This enforcement presumption is treated as rebuttable. In the 2010 Merger Guidelines, the enforcement presumption that a merger is anticompetitive is triggered when the post-merger $\mathrm{HHI}$ exceeds 2500 and the increase in the HHI exceeds 200 points. The 2010 Merger Guidelines also contain an enforcement presumption that mergers creating a post-merger HHI below 1500 are presumptively not-anticompetitive. Similarly, mergers are presumptively not-anticompetitive if the increase in the HHI is less than 100 points. ${ }^{48}$ These presumptions are rebuttable.

In a recent article, Malcolm Coate analyzed FTC Staff memoranda for mergers that raised unilateral effects concerns in the 1993-2010 time period following Baker Hughes. ${ }^{49} \mathrm{He}$ found that the combined market shares of the merging firms, the increase in the HHI, a proxy for the Gross Upward Pricing Pressure Index (GUPPI), and the number of remaining competitors all were highly informative in predicting agency enforcement decisions..$^{50}$ Coate determined that the FTC challenged more than 75 percent of the proposed mergers

\footnotetext{
${ }^{47}$ For further analysis, see the articles cited in Newmark, supra note 46.

${ }^{48}$ See 2010 Merger Guidelines, supra note 8, § 5.3.

${ }_{49}$ Malcolm B. Coate, Benchmarking the Upward Pricing Pressure Model with Federal Trade Commission Evidence, 7 J. Competition L. \& Econ. 825 (2011).

${ }^{50} \mathrm{Id}$. at $834-41$.
} 
with combined market shares of 60 percent or more. ${ }^{51}$ It challenged only 32 percent of the proposed mergers with combined market shares of less than 45 percent, and 63 percent of mergers with market shares in the 45-60 percent range. The existence of entry barriers strengthened this effect. If there were entry barriers, 86 percent of the mergers with combined market shares above 60 percent were challenged, and 71 percent of mergers with combined market shares above 45 percent were challenged.

Coate also found strong results in relating enforcement decisions to the number of remaining competitors and the increase in the HHI. Only 47 percent of mergers were challenged when the HHI increase was less than 800 points, but 86 percent were challenged when the HHI increase was more than 1000 points. He also found an over-90 percent challenge rate for transactions that led to three or fewer competitors when there were entry barriers, but a challenge rate of 17-23 percent in mergers resulting in markets of four or more competitors in the market. ${ }^{52}$

Entry barriers have become an important, if not essential, requirement. But, even where there are entry barriers, mergers were much less likely to be challenged by the FTC where the merger leaves at least four significant competitors, a combined market share of less than 60 percent, or an HHI increase of less than 800 points. ${ }^{53}$ The 30 percent market share threshold in PNB now appears less relevant to the FTC. In addition, analysis of Coate's data suggests that about 15 percent of mergers with HHI increases of at least 800 points were not challenged. ${ }^{54}$ Even where there were entry barriers, about 10 percent were not challenged. ${ }^{55}$ This data shows how the evidentiary presumptions

\footnotetext{
${ }^{51} \mathrm{Id}$. at 834 tbl.2. Coate has a companion article on mergers that raise coordinated effects concerns that is less detailed but suggests similar results. See Malcolm B. Coate, Collusion Theories in Merger Analysis: Still Alive and Kicking, 8 Competition Pol'y Int'L 105 (2012).

${ }^{52}$ Coate, supra note 49, at 834 tbl.2. These figures are based on Coate's "Raw Sample." His "Adjusted Sample" does not identify the number of firms when there are "Entry Issues" or "Proof of Concern."

53 These calculations also are based on Coate, "Table 2. Merger challenge rates by market structure, 1993-2010" [Excel spreadsheet on file with the author]. The spreadsheet uses Coate's data on challenge rates for different market share regions and the number of cases in each region to calculate the weighted average probabilities. Of course, an 800 point increase is quite large (e.g., a firm with a $40 \%$ market share acquiring a firm with a $10 \%$ market share, to achieve a $50 \%$ combined share). Moreover, it is noteworthy that the anticompetitive presumption in the 1992 Merger Guidelines was triggered by an HHI increase of 100, not 800, whereas the 2010 Merger Guidelines raise the presumption threshold up to an HHI increase of 200. See 2010 Merger Guidelines, supra note $8, \S 5.3$. Coate does not report HHI levels. But, if the increase in the HHI is 800 or more, it seems likely that the merger very often would fall into the highly concentrated region. For example, if a $40 \%$ firm acquires a $10 \%$ firm, the post-merger $\mathrm{HHI}$ contribution of those two firms alone would be 2500 points. Even if the transaction involved the merger of two $20 \%$ firms, they would contribute 1600 points to the post-merger HHI.

${ }^{54}$ Coate, supra note 49 , at 834 tbl.2.

${ }^{55} \mathrm{Id}$
} 
used in enforcement have changed over time in response to changes in economics and the law.

\section{INTERPRETING THE PRESUMPTIONS AND THEIR EVOLUTION WITH DECISION THEORY}

Decision theory provides a methodology for individual information gathering and decision making when information is imperfect and costly to obtain. This methodology can be described as a rational process by which a decision maker begins with some initial beliefs (i.e., presumptions) and then gathers additional information (i.e., evidence) to update beliefs in order to make a better decision. ${ }^{56}$ Decision theory also can be used to rationally gather information by balancing the costs and benefits of additional imperfect information.

Decision theory can be useful for understanding and formulating legal standards. ${ }^{57}$ In setting an economically rational legal standard for a particular category of conduct (e.g., merger, horizontal price restraint, tying, resale price agreements, etc.), an appellate court applying decision theory might begin with its initial presumptions about the likely competitive impact of conduct in that particular category. Those presumptions should be rationally based on economic theory, economic evidence about the category of conduct, and judicial experience with such conduct. These presumptions may be strongly or weakly held. In decision-theoretic terms, the presumptions may vary in the degree of uncertainty or in the variation regarding the outcome of the conduct. ${ }^{58}$

In setting the legal standard, the appellate court also would recognize that the district court could have the opportunity to gather evidence at trial, if such

\footnotetext{
${ }^{56}$ For a general introduction to decision theory, see Morris DeGroot, Optimal Statistical Decisions (1970). In the language of Bayesian probability theory, the decision maker begins with a "prior" probability, gathers information, and then forms a "posterior" probability by rationally combining the prior probability and the information. See, e.g., Howard RaIFFA, DeCIsion Analysis: Introductory Lectures on Choices Under Uncertainty 27-33 (1968); DeGRoot, supra, at 138-40.

${ }^{57}$ There is a large literature on the application of decision theory to antitrust. For a sample, see Isaac Ehrlich \& Richard A. Posner, An Economic Analysis of Legal Rulemaking, 3 J. Legal Stud. 257 (1974); C. Frederick Beckner III \& Steven C. Salop, Decision Theory and Antitrust Rules, 67 Antitrust L.J. 41 (1999).

${ }^{58}$ Legal presumptions sometimes also are based on policy considerations rather than (or in addition to) these economic considerations. For example, the presumption that the father of a child born to a married woman is the woman's husband flows from the probabilities. However, relevant DNA evidence may not be treated as admissible evidence for policy reasons regarding the maintenance of the family unit (and perhaps in order to ensure that the child has adequate financial support). June Carbone \& Naomi Cahn, The Past, Present and Future of the Marital Presumption, in The International Survey of Family Law 387 (Bill Atkin \& Fareda Banda eds., 2013).
} 
evidence is permitted by the legal standard chosen. The appellate court also would recognize that evidence (like other information) generally is incomplete and thus subject to error. For example, even if the evidence presented to the district court at trial tips on the side of implying that a merger is beneficial, it may be the case that the merger actually will turn out to be harmful, or vice versa.

Based on its presumptions and the likelihood that evidence at trial will point in an erroneous direction, the appellate court would set the legal standard and presumptions, including the burdens of production and persuasion to rebut the presumptions. The legal standard would instruct the district court on the amount, type, and certainty of the evidence required to find liability (or non-liability) at trial. ${ }^{59}$

The standard would recognize that the district court would face uncertainty, and its decisions sometimes will be erroneous as a result. Sometimes individual facts or even the totality of the evidence is subject to multiple interpretations or points in an erroneous direction. Decision theory recognizes that such errors are inevitable because information is limited and imperfect. Decision theory also recognizes that the cost of information implies that it will not be economical to achieve perfect information and so may be economical to restrict the amount of information that is introduced into the decision process. Decision theory also would recognize that certain information might be so subject to error or misinterpretation that it might make sense to exclude it. ${ }^{60}$

The legal standard would optimally balance the consumer welfare costs from the district court erroneously prohibiting beneficial conduct or from erroneously permitting harmful conduct. This analysis of the costs of error would include the impact of the legal rule on deterrence, that is, on future participants' choice of conduct in light of the legal standard. ${ }^{61}$ It would not simply be limited to erroneous application of the particular legal standard. It also might take into account the cost of delay in the administrative process.

\footnotetext{
${ }^{59}$ See generally Louis Kaplow, Burden of Proof, 121 YaLE L.J. 738, 758-62 (2012) (discussing how raising and lowering the evidence threshold required to convict impacts the incidence of false positives and negatives).

${ }^{60}$ One possible example would be the inadmissibility of a rape victim's previous sexual history, or a defendant's previous criminal record. For a recent discussion of the latter issue, see James B. Jacobs, Admissibility of the Defendant's Criminal Records at Trial, 4 Beising L. Rev. 120 (2013), available at www.scirp.org/journal/PaperDownload.aspx?paperID=37526.

${ }^{61}$ Deterrence effects are separate from the issue of judicial errors for a given legal standard. For example, a rule of per se legality would be easy to administer and would not lead a district court to issue erroneous "false convictions." But, such a legal standard might not be optimal because it would not deter any anticompetitive conduct in that category.
} 
The resulting legal standards themselves can be framed as presumptions and associated burdens of production and persuasion. ${ }^{62}$ For example, the "quick look to condemn" legal standard for horizontal price agreements ${ }^{63}$ involves a rebuttable presumption that conduct in this category is inherently likely to be anticompetitive. ${ }^{64}$ The standard places a burden of production or persuasion on the defendants to show that the agreement raises cognizable and agreement-specific procompetitive benefits.

The current burden of production placed on the defendants to rebut the presumption appears to be one of showing that competitive benefits are "plausible" and "conduct-specific." The current burden of proof appears to be one of establishing plausible benefits with "substantial evidence." However, it is noteworthy that a hypothetical appellate court applying decision theory could have set the burden of production higher than "plausibility." It also could have set the burden of proof higher than "substantial evidence," say, a standard of "clear and convincing" evidence or "clear showing." For example, the PNB Court set a "clear showing" for rebutting the plaintiff's prima facie case based on the anticompetitive presumption.

In a horizontal price-setting case, if the defendant carries this burden of production and the plaintiff fails to rebut the defendant's efficiency evidence, the burden would shift back to the plaintiff under the rule of reason to show anticompetitive harm. ${ }^{65}$ If this showing of harm is not rebutted, then the bur-

\footnotetext{
${ }^{62}$ For a related, insightful discussion that is framed more solidly in terms of legal procedure, see Andrew I. Gavil, Burden of Proof in U.S. Antitrust Law, in 1 ABA Section of Antitrust Law, Issues in Competition Law and Policy 125 (W. Dale Collins ed., 2008).

${ }^{63}$ For this terminology, see the discussion in Andrew I. GaviL, William E. Kovacic \& Jonathan B. Baker, Antitrust Law in Perspective: Cases, Concepts and Problems in Competition Policy 210 fig.2-9 (2d ed. 2008).

${ }^{64}$ See, e.g., Polygram Holding, Inc. v. FTC, 416 F.3d 29 (D.C. Cir. 2005).

${ }^{65}$ See, e.g., Law v. NCAA, 134 F.3d 1010, 1019 (10th Cir. 1998) (Sherman Act Section 1 context); FTC v. Univ. Health, Inc., 938 F.2d 1206, 1218-19 (11th Cir. 1991) (same); United States v. Baker Hughes Inc., 908 F.2d 981, 982-83 (D.C. Cir. 1990) (merger context). For a Section 2 example, see United States v. Microsoft Corp., 253 F.3d 34, 54-55 (D.C. Cir. 2001) (en banc) (per curiam). This burden-shifting approach is flawed if it is interpreted to require exactly the same rigid sequential decision-making process in all cases. For example, decision theory also suggests that a sequential decision process be structured to focus first on the leastcost and most likely dispositive evidence, ceteris paribus. For further analysis, see Beckner \& Salop, supra note 57. Thus, for example, evidence that conduct lacks any cognizable efficiency benefits could be used to buttress an inference of harm to competition in Section 2 cases, not just Section 1. This is because the evidence of lack of procompetitive purpose suggests that both the effect and the purpose of the conduct were to create competitive harms. Thus, the court might adjust the sequence of the burden-shifting in light of that evidence. In addition, trials that are not truncated by summary judgment provide a full record on all of the issues. This reduces or eliminates a benefit of a sequential, burden-shifting decision process by the court or jury. See, e.g., Steven C. Salop et al., The Appropriate Legal Standard and Sufficient Economic Evidence for Exclusive Dealing under Section 2: The FTC's McWane Case (Geo. L. Faculty Publications \& Other Works, Paper 1365, 2014), available at scholarship.law.georgetown.edu/facpub/1365.
} 
den would shift back to the defendant again to produce evidence of actual efficiencies, not simply plausible conduct-specific efficiency benefits. If that benefits evidence is not rebutted by the plaintiff, then the burden of production shifts back to the plaintiff and merges with the ultimate burden of persuasion to show that the magnitude and likelihood of competitive harm outweighs the likelihood and magnitude of the unrebutted efficiency benefits, that is, that consumers and the competitive process are harmed on balance. In each of these steps, rational beliefs about the likelihood of procompetitive and anticompetitive effects might affect the burden of production placed on the party.

Standards of per se illegality also can be interpreted through the lens of decision theory. Evidence generally is imperfect, and will seldom resolve all uncertainties. In some circumstances, additional evidence may lead to more error, not less. Evidence also is costly. The cost of the evidence may involve the cost of delay as well as out-of-pocket costs of the parties and administrative costs of the courts. For these reasons, it may be most efficient to base a decision solely on initial presumptions. This is more likely when the decision maker has strong economic presumptions and the available evidence is particularly costly, imperfect, or highly subject to misinterpretation. ${ }^{66}$

\section{A. Technical Analysis of Economic Presumptions and IMPERFECT EVIDENCE}

This decision-making process can be made more concrete with a more technical illustration of the creation of rebuttable presumptions based on likely (albeit imperfect) prior beliefs or preliminary evidence. ${ }^{67}$ Suppose that conduct in a certain category is considered anticompetitive if the consumer harms from the effects of the conduct on market power (denoted by $H$ ) exceed the efficiency benefits passed on to consumers (denoted by $B$ ). Suppose that a full trial would reveal evidence on $H$ and $B$, but not necessarily the true values. Thus, a trial might find the correct result, or it might lead to either a false conviction ("false positive") or false acquittal ("false negative"). For this sim-

\footnotetext{
${ }^{66}$ Deciding solely on the basis of an evidentiary presumption may have the unintended effect of entrenching erroneous presumptions. In decision theory, this is a type of "two-armed bandit" problem. Facing two slot machines with uncertain payoffs and a bad run on what actually is the more favorable machine, a gambler may settle on playing the inferior machine and rationally may find it economical to forgo further experimentation (i.e., failing to make any additional plays on what actually is the more favorable machine). For further details, see Michael Rothschild, A Two-Armed Bandit Theory of Market Pricing, 9 J. ECON. Theory 185 (1974). This twoarmed bandit problem is the logical underpinning of Frank Easterbrook's characterization of the inhospitality tradition and associated per se rules deterring conduct that may turn out to be procompetitive. See Frank H. Easterbrook, The Limits of Antitrust, 63 Tex. L. Rev. 1 (1984).

${ }^{67}$ For a similar approach, see the recent article on burden of proof by Louis Kaplow, supra note 59 .
} 
ple illustrative exercise, we assume that the effects on deterrence and the cost of the evidence can be ignored. ${ }^{68}$

Suppose that economic theory, empirical analysis, and judicial experience suggest to an appellate court that it is highly likely that harms exceed benefits $(H>B)$ for this particular category of conduct. For example, to make this concrete, suppose for this category of conduct that the "expected value" of $H$ (denoted by $E H$ ) is $\$ 150$, and very likely falls in the $\$ 100-200$ range, while the expected value of $B$ (denoted by $E B$ ) is $\$ 100$ and very likely falls in a lower range, say $\$ 80-120$. Suppose that values of $H<\$ 120$ and $B>\$ 100$ are relatively unlikely. ${ }^{69}$ Based on this information, conduct in this category can be strongly presumed to be harmful. This is because, absent additional evidence, the court's best and confident estimate is that $E H>E B$. This is an economic presumption.

The cost of error in this situation is also simple to illustrate. If the conduct is prohibited, but $B>H$, then the cost of this "false positive" is the difference in the values, or $B-H>0$. If the conduct is permitted, but $H>B$, then the cost of this "false negative" also is the difference in the values, or $H-B>0$.

Suppose that a trial on the merits would reveal relevant evidence on the actual values of $H$ and $B$. However, suppose that the evidence would be imperfect and might lead to either an overestimate or an underestimate of the true values. Depending on the reliability of the likely evidence and the strength of the presumption, it might not make economic sense to have a trial to gather additional evidence, even putting aside any costs of administration and delay that a trial might entail. This would be the case if the probability is small that the evidence reliably would reveal that the true $H$ is less than the true $B$. This decision making involves two parts. First, it may be unlikely that the evidence would suggest that $B>H$. Second, even if the evidence suggests that $B>H$, that evidence may be erroneous, that is, $B$ may actually be less than $H$.

In these circumstances, it would not make sense to have a trial. It would make more sense to apply a standard of per se illegality to this category of conduct, that is, adopt a conclusive presumption that the conduct is anticompetitive. The potential cost of error from adopting this conclusive presumption

\footnotetext{
${ }^{68}$ While the illustrative analysis here assumes a single trial, "errors" more generally focus on over-deterrence or under-deterrence, relative to optimal deterrence. Errors a court would make in administering the standard then feed into the issue of deterrence but are not the central concern. For example, a standard requiring capital punishment for overtime parking might lead to zero violations and hence no errors by the court administering the standard. But it surely would lead to over-deterrence.

${ }^{69}$ To make this more technical, suppose the probability that the true $H$ is below $\$ 120$ is $5 \%$, and the probability that the true $B$ is above $\$ 120$ also is $5 \%$.
} 
represents the forgone net consumer benefits $B-H$ multiplied by the probability that the presumption erroneously prevents this beneficial conduct. However, this expected cost of error may be far less than the expected error cost from a rule of reason or a rule of per se legality.

The idea that the evidence may be unlikely to establish a situation with $B>H$ is illustrated in Figure 1. The curve on the right shows the likelihood of various possible true values of $H$ for this category of conduct. The curve on the left shows the likelihood of various possible true values of $B$. The finding that $B>H$ is only possible if the true values of $B$ and $H$ both fall in the overlap (and shaded) portion of the curves. For these pictured distributions, that outcome is very unlikely because the overlap in the $B$ and $H$ distributions is so narrow. In addition, the likely forgone net benefits $B-H>0$ from errors that might occur with a conclusive presumption (per se illegality) also are small.

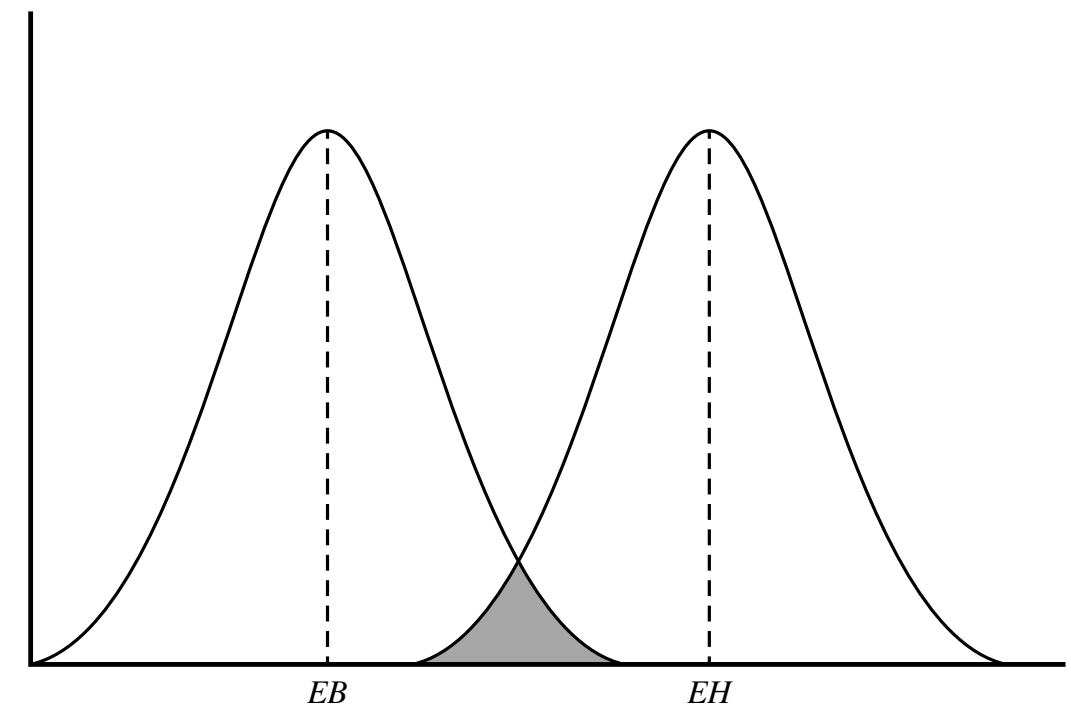

FIGURE 1:

\section{NARROW OVERLAP IN EXPECTED BENEFITS AND HARMS}

Contrast the distributions in Figure 1 to those shown in Figure 2 below for a different category of conduct. For this conduct, the ranges of the values of $H$ and $B$ are much broader and there is more overlap in the two distributions. Thus, it is more likely that evidence at trial would reveal $B>H$, assuming that the evidence is reasonably reliable. In Figure 2, it is more likely that gathering reliable evidence at trial would yield a different conclusion than would be indicated solely by the presumptions reflected by the difference in expected 
values, though the presumption might affect the evidentiary burden. In addition, the potential net benefits $(B-H>0)$ potentially forgone from a rule of per se rule illegality also are much larger. Thus, if evidence is reasonably reliable, it would make more economic sense to permit a trial to introduce evidence on $B$ and $H$ here than it would for the conduct in Figure 1, ceteris paribus.

In terms of legal standards and presumptions, an appellate court might adopt a rule of per se illegality for the category of conduct in Figure 1. But it might adopt a rule of reason standard for the category of conduct in Figure 2. Per se illegality would, of course, also be more likely to be the better legal rule if the evidence that would be introduced at trial were likely unreliable, as discussed next. ${ }^{70}$



FIGURE 2:

\section{BROAD OVERLAP IN EXPECTED BENEFITS AND HARMS}

This decision-theoretic reasoning can also explain the benefits of a rebuttable presumption of illegality. Even for a category of conduct with values of $B$ and $H$ as in Figure 1, a rebuttable presumption of illegality might be superior to a standard of per se illegality or the full rule of reason. With the rebuttable presumption, the defendant would only carry the case to trial if it believed that it had a significant probability of prevailing, in light of its anticipation of the evidence. If the evidence were unequivocal (i.e., perfectly accurate), for ex-

\footnotetext{
70 The efficacy of a conclusive economic presumption does not require an assumption that the evidence at trial would be imperfect. Suppose that the defendant can produce perfectly unequivocal evidence of the true values of $B$ and $H$. If it is sufficiently costly to obtain the evidence, a rational decision maker might choose to make the decision on the basis of the expected values (i.e., the economic presumption), rather than pay the cost of the evidence. This type of comparison might be most relevant for determining standards for (say) surviving a motion to dismiss on a conspiracy claim. Bell Atl. Corp. v. Twombly, 550 U.S. 544 (2007). For merits claims, the issue of imperfectly reliable evidence may be more relevant than the cost of the process.
} 
ample, this standard clearly would lead to a reduced incidence of error. If this approach would not inflict high costs on the plaintiff and the court, it would be better to adopt a quick look "to condemn" standard that places the burden on the defendant. ${ }^{71}$ This standard makes sense because of the rational presumption that the conduct is anticompetitive, plus the defendant's access to reliable evidence to possibly rebut the presumption.

However, suppose instead that the evidence were known to be less than perfectly reliable, either inherently uncertain to some degree or perhaps highly subject to misinterpretation by the fact finder. In this case, even ignoring the cost of discovery and trial, the fear of introducing evidentiary error might increase the benefits of a conclusive presumption. To make this idea concrete, consider a category of cases where the evidence might produce a value of $H$ that is not equal to the true value $H^{t}$, but differs according to the distribution in Figure 3 below. Suppose that a similar distribution of benefits evidence around the true value $B^{t}$ also could occur. In Figure 3, even though the true harms $H^{t}$ exceed the true benefits $B^{t}$, relying on the evidence at trial yields a significant likelihood of erroneously predicting that $B>H$. Suppose that $E H$ $>E B$, as assumed earlier, but with a moderately wide variation. In this situation, an appellate court nonetheless might adopt a conclusive presumption that $B<H$, out of fear that a trial is too likely to reach an erroneous decision, which would fail at optimal interdiction, and perhaps also lead to worsened deterrence.

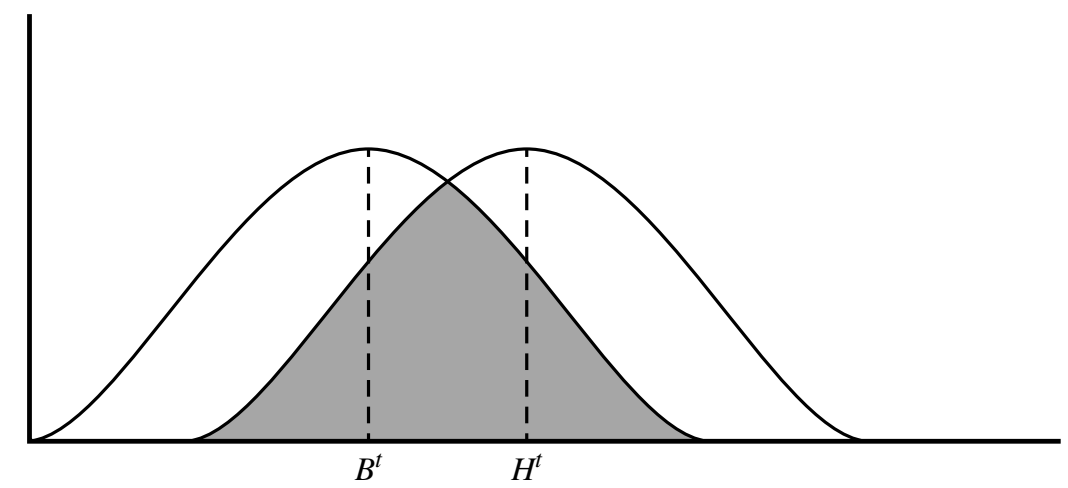

FIGURE 3: IMPERFECTLY RELIABLE EVIDENCE

Rather than a conclusive presumption, the appellate court might do better by adopting instead a rebuttable presumption that $B<H$, but require the defendant to make a more definitive showing that $B>H$. This more definitive

${ }^{71}$ For example, see the discussion in GAVIL ET AL., supra note 63, at 210 fig.2-9. 
showing can be framed as either a higher burden of persuasion or a higher burden of production. This can be explained by extending the example.

Suppose that the defendant produces unequivocal evidence that $H=H^{t}$. The burden of persuasion approach would require the defendant to show with a high probability that $B>H^{t}$. The burden of production approach might be interpreted to require the defendant to show with 51 percent probability that $B$ exceeds $H$ by a particular amount, say $B>H^{t}+D$. By setting a higher differential $D$, the court increases the likelihood that the $B$ evidence is more likely to reflect that the true $B^{t}>H^{t}$, rather than the opposite. The optimal differential $D$ would depend on the imperfections in the evidence and the costs of errors, both in terms of imperfect interdiction (i.e., net benefits lost and net harms suffered in particular cases) and imperfect deterrence from erroneous findings.

The burden of production approach sketched above can be seen as an alternative conceptualization of the "clear showing" standard. If $B$ exceeds $H$ by at least a large value of $D$, that evidence would represent a "clear showing" that $B>H$. The approach also illustrates the decision-theoretic role of "disproportionate effects" standards. ${ }^{72}$

\section{B. Properly Combining Presumptions and Imperfect Evidence: The Application of Bayes' Law}

The appropriate standard for imperfectly reliable evidence also can be usefully framed as a Bayesian decision process. ${ }^{73}$ Bayes' Law states a mathematical relationship among probabilities that provides a way to combine an initial probability estimate ("prior") and additional information ("support" or "evidence") to generate an improved probability estimate ("posterior"). ${ }^{74}$ Suppose, for example, that there is an accurate "prior" economic presumption (based on experience, economic theory, and empirical evidence) that mergers falling into a particular category (e.g., high combined market share, high concentration) have, say, an 80 percent probability of being harmful (i.e., an-

\footnotetext{
${ }^{72}$ For example, Areeda and Hovenkamp have suggested a disproportionate harm standard for Section 2 cases. 3 Phillip E. Areeda \& Herbert Hovenkamp, Antitrust Law: An Analysis of Antitrust Principles and Their Application II 651a, at 96 (3d ed. 2008).

${ }^{73}$ There is a large literature on the Bayesian approach to evidence. For example, see D.H. Kaye, What Is Bayesianism? A Guide for the Perplexed, 28 Jurimetrics J. 161 (1988); Richard D. Friedman, A Presumption of Innocence, Not of Even Odds, 52 Stan. L. Rev. 873 (2000), and the references cited therein. For one essay on the history of Bayes' Law, see Stephen M. Stigler, Who Discovered Bayes' Theorem?, 37 Am. Statistician 290 (1983).

${ }^{74}$ In mathematical notation, the probability that Event $E$ occurs, conditional on Event $F$ occurring $(\operatorname{Pr}(E \mid F))$ is given by $\operatorname{Pr}(E \mid F)=\operatorname{Pr}(F \mid E) \operatorname{Pr}(E) / \operatorname{Pr}(F)$, where $\operatorname{Pr}(F \mid E)$ is the probability that Event $F$ occurs, conditional on Event $E$ occurring, and $\operatorname{Pr}(E)$ and $\operatorname{Pr}(F)$ are the conditional probabilities of Events $E$ and $F$ occurring. $\operatorname{Pr}(E)$ is the "prior" probability, $\operatorname{Pr}(E \mid F)$ is the updated, "posterior" probability and the ratio $\operatorname{Pr}(F \mid E) / \operatorname{Pr}(F)$ is the "support" for the updating.
} 
ticompetitive), absent additional evidence. Thus, mergers in this category would involve a very strong anticompetitive economic presumption.

Suppose that it is anticipated that the "supporting" evidence at trial on balance might well indicate that the merger actually is beneficial. But assume that the evidence inevitably would be mixed and imperfect, so that the probability is 25 percent that such evidence actually could make an erroneous prediction in either direction. That is, suppose the trial evidence that a merger is harmful on balance has a 25 percent likelihood of being erroneous. Similarly, suppose the trial evidence that a merger is beneficial on balance also has a 25 percent likelihood of being erroneous. To simplify the technical analysis, assume as before that the consumer harm from false convictions and false acquittals are identical and that deterrence effects can be ignored. ${ }^{75}$

Given these assumptions, suppose that a trial is held and the evidence at trial points to the merger being beneficial. Notwithstanding this factual evidence at trial, the combination of the strong and rational anticompetitive presumption, and the knowledge that the evidence is potentially unreliable, may imply a conclusion that the merger nonetheless is more likely to be harmful than beneficial. That is, the probability that the merger is anticompetitive may remain above 50 percent, even after taking the imperfectly reliable evidence of competitive benefits into account.

In fact, a Bayesian analysis using the empirical assumptions made above indicates that the probability of the merger being anticompetitive is 57 percent, as shown below. Thus, in this situation, the economic presumption would trump the value of the imperfect evidence that would be shown at trial. Evidence known to have a 25 percent error rate would be insufficient to offset the 80 percent accurate presumption. Stated simply, the presumption points to the wrong conclusion only 20 percent of the time, whereas the evidence signals the wrong result 25 percent of the time. The presumption implies an evidentiary burden that the evidence be reliable enough to trump the presumption. That is, it must point to the correct result with a probability exceeding 80 percent.

This decision-theoretic result can be illustrated and explained with Table 2 below, which sets out the "frequencies" of each of the four possible outcomes of the trial. ${ }^{76}$ These four outcomes are: (1) evidence of the fact that the merger

\footnotetext{
${ }^{75}$ For example, suppose that $B-H$ can take on only two values, say +100 or -100 . The appellate court's presumption represents the probability that a merger in this category is either truly anticompetitive (i.e., $B-H=-100$ ) or truly procompetitive (i.e., $B-H=+100$ ).

${ }^{76}$ For further details on the use of frequency tables to analyze Bayes' Law issues, see Steven C. Salop, Evaluating Uncertain Evidence with Sir Thomas Bayes: A Note for Teachers, J. Econ. Persp., Summer 1987, at 155; Gerd Gigerenzer \& Ulrich Hoffrage, How to Improve Bayesian Reasoning Without Instruction: Frequency Formats, 102 Psych. Rev. 684 (1995).
} 
is beneficial and the merger actually is beneficial; (2) evidence suggesting that the merger is harmful and the fact that the merger actually is harmful; (3) evidence suggesting the merger is beneficial and the fact that the merger actually is harmful; and (4) evidence suggesting that the merger is harmful and the fact that the merger actually is beneficial. In the first two outcomes, the evidence correctly points to a conviction or acquittal. But, in the latter two outcomes, the evidence is unreliable and suggests the wrong outcome of the merger. These latter two outcomes are errors. If the evidence were admitted and relied upon by the district court for its decision, outcome (3) would correspond to an erroneous acquittal and outcome (4) would correspond to an erroneous conviction.

Consider a group of 100 mergers in this general category, as shown in Table 2. If the 80 percent presumption is valid, it implies that on average 80 of those 100 mergers are harmful (i.e., anticompetitive) and 20 are beneficial (i.e., procompetitive), as indicated in the last column. The evidence proffered at trial is assumed to be imperfect with a 25 percent likelihood of being incorrect. This predicts that on average the evidence at trial erroneously would predict that 25 percent of the 80 harmful mergers are beneficial, or a total of 20 , as shown in the second row in the left column. In contrast, the evidence at trial on average correctly would predict that 75 percent of the 80 harmful mergers are beneficial, or a total of 60 . For the 20 beneficial mergers, the evidence at trial on average would incorrectly predict that 5 (i.e., 25 percent) are harmful, while 15 (i.e., 75 percent) others on average would correctly be predicted to be beneficial, as shown in the top row.

Examining the first column, the evidence would predict that 35 of the mergers would be beneficial. But, in fact, only 43 percent (i.e., 15 out of 35) of the mergers predicted by the evidence to be beneficial actually are beneficial. In contrast, 57 percent (i.e., 20 out of 35) actually are harmful. ${ }^{77}$ Thus, in this case, the trial evidence that the merger is beneficial is incorrect more often than it is correct. In this situation, it would not make sense to hold trials for these 100 cases. The presumption of harm is more reliable than the imperfect evidence.

This logic of the frequency table also applies to a single merger. If the characteristics of a category of mergers suggest that such mergers are likely to be harmful on balance with probability of 80 percent, then the legal standard should place an evidentiary burden on defendant to rebut this 80 percent presumption. If the available evidence in this type of case is inherently highly unlikely to be able to reach this level of reliability, then the appellate court

\footnotetext{
${ }^{77}$ In contrast, of the 65 mergers signaled to be harmful by the evidence, almost all of them (60) actually are harmful.
} 
can mandate and the trial court can apply a per se rule-that is, a conclusive anticompetitive presumption - in order to avoid a trial that should be unable to reach a reliable contrary conclusion.

Alternatively, the appellate court could mandate a trial but set the evidentiary burden at a high level. For example, if the evidence that the merger is beneficial were not subject to any error, but were perfectly unequivocal, then that evidence could rebut even the 80 percent anticompetitive economic presumption. More generally, the defendant should be required to produce evidence sufficient to establish with a probability of at least 80 percent that the merger actually is not anticompetitive. Whether stated in terms of burden of production or burden of persuasion, the defendant's rebuttal evidence must be strong and reliable enough to trump the anticompetitive presumption.

TABLE 2

STRONG PRESUMPTION TRUMPS IMPERFECT EVIDENCE

Trial Evidence

\begin{tabular}{lccc}
$\begin{array}{l}\text { Effects } \\
\text { In Fact }\end{array}$ & Beneficial & Harmful & $\begin{array}{c}\text { Total } \\
\text { (per presumption) }\end{array}$ \\
\hline Beneficial & 15 & 5 & 20 \\
Harmful & 20 & 60 & 80 \\
Total & 35 & 65 & 100
\end{tabular}

This logic can be illustrated by changing the assumptions of the example. In Table 3, it is assumed that the evidence produced by the defendant is more reliable, in the sense that it is only 10 percent likely to be incorrect, rather than 25 percent as in Table 2. In this situation, the more reliable evidence of benefits would be able to trump the presumption of harm, unlike the case where the evidence was less definitive. As shown in Table 3, when the evidence that the merger is beneficial is more reliable, the probability that the merger is actually beneficial now is more likely correct than incorrect. In this example, the probability that the evidence correctly signals a beneficial merger is about 70 percent. Of the 26 mergers predicted by the evidence to be beneficial, 18 actually are beneficial. ${ }^{78}$ Again, this same logic can be applied to a single merger rather than a group of mergers.

${ }^{78} 18 / 26=69.2 \%$. 
TABLE 3

MORE RELIABLE EVIDENCE TRUMPS PRESUMPTION

Trial Evidence

\begin{tabular}{lccc}
$\begin{array}{l}\text { Effects } \\
\text { In Fact }\end{array}$ & Beneficial & Harmful & $\begin{array}{c}\text { Total } \\
\text { (per presumption) }\end{array}$ \\
\hline Beneficial & 18 & 2 & 20 \\
Harmful & 8 & 72 & 80 \\
Total & 26 & 74 & 100
\end{tabular}

The relationship between the strength of the presumption and the reliability of the evidence follows in a straightforward way. The evidence should trump the presumption when the evidence is more reliable than the presumption, and the presumption should rule when the evidence is less reliable. If the presumption is that 80 percent of the mergers in this category are harmful, then evidence that a merger is beneficial can trump the presumption only if the evidence is subject to error 20 percent or less of the time. This balance is illustrated in Table 4 below. Of the 32 mergers predicted to be beneficial by the evidence, exactly half (16) actually are beneficial.

TABLE 4

EVIDENCE AND PRESUMPTION IN EQUAL BALANCE

Trial Evidence

Effects

Total

\begin{tabular}{lccc} 
In Fact & Beneficial & Harmful & (per presumption) \\
\hline Beneficial & 16 & 4 & 20 \\
Harmful & 16 & 64 & 80 \\
Total & 32 & 68 & 100
\end{tabular}

These three examples can help to interpret the adoption of the $P N B$ presumption in 1963, or any other presumption in any type of antitrust case. ${ }^{79}$ A stronger presumption of harm would lead to a higher burden on the defendant to rebut the presumption. When the anticompetitive economic presumption is stronger, it is rational for the appellate court to set a legal standard with an anticompetitive presumption that places a higher burden of production and persuasion on the merging parties to produce more reliable

\footnotetext{
${ }^{79}$ There is a long literature on the proper interpretation of presumptions, including interpretations and criticism of Coffin v. United States, 156 U.S. 432 (1895). For example, see Bryce Rea, Jr., Note, The Presumption of Innocence in Criminal Cases, 3 WASH. \& LeE L. Rev. 82 (1941); George G. Olshausen, Comment, Evidence: Presumptions as Evidence-A Reply, 31 Calif. L. Rev. 316 (1943). For a modern summary, see Paul F. Rothstein, Federal Rules of EVIDENCE 59-79 (2013-2014 ed.).
} 
evidence that the merger actually is beneficial. Weak evidence rationally would not be sufficient to trump the strong presumption. In the language of the $P N B$ opinion, a "clear showing" rebuttal standard would make economic sense when there is a strong economic presumption that mergers in this category very likely are anticompetitive.

Courts' post- $P N B$ transition to a weaker anticompetitive presumption also can be explained in these decision-theoretic terms. Economic analysis since $P N B$ has indicated that the predictive power of high concentration is weaker than previously believed. This rationally would lead to a weaker rebuttable presumption by the courts. Thus, the appropriate evidentiary placed burden on the defendant to rebut the prima facie case would be lowered. As stated in Baker Hughes:

\begin{abstract}
Imposing a heavy burden of production on a defendant would be particularly anomalous where, as here, it is easy to establish a prima facie case. The government, after all, can carry its initial burden of production simply by presenting market concentration statistics. To allow the government virtually to rest its case at that point, leaving the defendant to prove the core of the dispute, would grossly inflate the role of statistics in actions brought under section 7 ... Requiring a "clear showing" in this setting would move far toward forcing a defendant to rebut a probability with a certainty. ${ }^{80}$
\end{abstract}

In decision-theoretic terms, this change suggests that weaker evidence can be sufficient to trump the now-weaker presumption. This result can be shown by changing the frequency table from the previous example. Suppose that the anticompetitive economic presumption were weaker, only 60 percent instead of 80 percent. However, suppose that the evidence has a 25 percent chance of pointing in the wrong direction. With a weaker anticompetitive presumption, evidence at trial that the merger is beneficial is more likely to be able to overcome the economic presumption.

As shown in Table 5 below, when the evidence points to the merger being beneficial, and the anticompetitive presumption is only 60 percent, then the probability that the merger is actually beneficial is 67 percent (i.e., 30 out of 45). In contrast, the corresponding probability that the merger is beneficial was only 43 percent in Table 2, when the anticompetitive presumption was stronger, at 80 percent. This shows that when the presumption becomes weaker, the burden of production on the defendant required to rebut the presumption should fall accordingly. ${ }^{81}$

\footnotetext{
${ }^{80}$ United States v. Baker Hughes Inc., 908 F.2d 981, 981-92 (D.C. Cir. 1990).

${ }^{81}$ Similarly, even though mergers involve horizontal price agreements between the merging parties, the law does not require the merging parties to show plausible economic efficiencies. The existence of some merger-specific efficiencies currently are seen as generally plausible, resulting from the integration of assets involved in the merger, so that the initial presumption about horizontal agreements is assumed to be rebutted. However, this assumption may not al-
} 
TABLE 5

IMPERFECT EVIDENCE DOMINATES WEAKER PRESUMPTION

Trial Evidence

\begin{tabular}{lccc}
$\begin{array}{l}\text { Effects } \\
\text { In Fact }\end{array}$ & Beneficial & Harmful & $\begin{array}{c}\text { Total } \\
\text { (per presumption) }\end{array}$ \\
\hline Beneficial & 30 & 10 & 40 \\
Harmful & 15 & 45 & 60 \\
Total & 45 & 55 & 100
\end{tabular}

This Bayes' Law analysis also can be used to interpret the statement in Baker Hughes that "[r]equiring a 'clear showing' in this setting would move far toward forcing a defendant to rebut a probability with a certainty." ${ }_{2}$ The reliability of the evidence required to rebut a presumption depends on the relative probabilities of error of each. When the presumption has a 40 percent probability of being incorrect and the evidence has only a 25 percent likelihood of error, as in Table 5, then the more reliable evidence should rebut the presumption. But, when the presumption has only a 20 percent probability of being incorrect, while the evidence has a 25 percent likelihood of error, as in Table 2, then this less reliable evidence should be insufficient to rebut the stronger presumption.

The sliding scale standard of Baker Hughes and Heinz similarly can be interpreted through the lens of decision theory. The higher the level of concentration and combined market shares, the less likely that there is such substantial overlap in the ranges of $H$ and $B$ ceteris paribus, and so the stronger would be the anticompetitive economic presumption. Taking into account the Bayesian analysis of imperfect evidence in Tables 2-5, the appellate court might instruct the district court that the defendants would have to produce stronger, more reliable evidence in order to trump the stronger presumption for this category of conduct. Again, this can be seen by comparing the results in Tables 2 and 5. Table 5 would correspond to the lower level of concentration (or other market structure evidence), and Table 2 would correspond to the higher level.

This decision theory approach also can be applied to conduct across all of antitrust, not just mergers. For example, an anticompetitive presumption might be applied to exclusive dealing by a monopolist that affects most or all distributors. This anticompetitive presumption would be stronger if the monopolist's conduct lacked cognizable efficiency benefits. The same

ways be appropriate for partial ownership acquisitions where (unlike mergers) there is no integration of production or R\&D. It also might not apply to the acquisitions of patents by a patent aggregation entity for non-complementary patents.

${ }_{82}$ Baker Hughes, 908 F.2d 981. 
approach also can be applied to conduct with a procompetitive presumption. For example, the use of non-price vertical restraints by the firm that lacks market power might be seen as presumptively beneficial. In either case, the strength of the evidentiary presumption would need to be determined to set the rebuttal standard for contrary evidence.

This analysis also highlights why the distinction between the burden of production and the burden of proof is "elusive." Hughes ("requiring a 'clear showing' in this setting would move far toward forcing a defendant to rebut a probability with a certainty") interpreted the $P N B$ "clear showing" standard as a burden of persuasion, not just as a burden of production. ${ }^{84}$ In decision-theory terms, the distinction between burden of production and burden of persuasion is less clear ${ }^{85}$ Evidence is characterized as more reliable (or less equivocal) if it has a lower probability of erroneously predicting the true outcome (10 percent vs. 25 percent in the examples). That requirement of greater reliability can be interpreted as a difference in the burden of production: when the burden of production is higher, the defendant is required to produce more evidence to establish that higher level of reliability.

However, this also can be interpreted as a difference in the burden of persuasion, in that the more reliable evidence is less likely to be erroneous. That is, if the likelihood that the evidence leads to an erroneous prediction is only 10 percent or less, the evidence might be said to satisfy a "beyond a reasonable doubt" standard. In contrast, if the likelihood that the evidence leads to an erroneous prediction is (say) 25 percent, then the evidence might be said to satisfy only a "clear and convincing" standard. And, if the probability of being erroneous is, say, 45 percent, then the evidence might be said to satisfy only a "preponderance of the evidence" standard. ${ }^{86}$

${ }^{83}$ As explained in Baker Hughes, the distinction between the defendant's burden of production and the ultimate burden of persuasion is "always an elusive distinction in practice." Id. at 991.

${ }^{84} I d$. at 992 (finding the "clear showing" standard would enable the prosecution to "virtually rest its case" on $P N B$ 's weak concentration presumption, "leaving the defendant to prove the core of the dispute").

${ }^{85}$ For an overview of authority discussing the traditional distinction between the burden of proof and burden of persuasion, see Kaplow, supra note 59, at 738, 742 n.5.

86 This complements the earlier example of this same point. Suppose that the defendant produces unequivocal evidence that $H=H^{t}$. The burden of persuasion approach would require the defendant to show with a high probability that $B>H^{t}$. The burden of production approach might require the defendant to show with $51 \%$ probability that $B$ exceeds $H$ by a particular amount, say $B>H^{t}+D$. By setting a higher differential $D$, the court increases the likelihood that the $B$ evidence is more likely to reflect that the true $B>H^{t}$, rather than the opposite. By placing a "thumb on the scale" in this way, a higher burden of persuasion is converted into a higher burden of production. 
This analysis also raises the issue of the distinction between relevant evidence and a rebuttable presumption. One interpretation is that a rebuttable presumption is a "conclusion from judicially noticed circumstantial evidence." ${ }^{87}$ This circumstantial evidence may be predictive of the conclusion, or it may involve a policy determination, as noted earlier. Thus, the conclusion drawn from the circumstantial evidence is assumed by the decision maker as a general matter, rather than made on the basis of evaluation in the particular case. Moreover, whichever the source of the conclusion, the conclusion is strong enough that it is sufficient by itself to satisfy the party's burden. The presumption shifts the burden to the opposing party.

Because the presumption can be rebutted, its effect resembles relevant evidence that can be rebutted with opposing relevant evidence. ${ }^{88}$ However, the presumption may be sufficiently strong that the burden on the opposing party to rebut the presumption may be quite high. For example, the presumption of innocence in a criminal case can only be rebutted by proof of guilt "beyond a reasonable doubt."

\section{Optimal Deterrence}

The analysis becomes more complicated when deterrence effects are taken into account. The concepts of false positives and false negatives then would be expanded to include the impact on deterrence. The concept of false positives is expanded to include procompetitive mergers that are not even proposed as a result of the legal standard-that is, over-deterrence. The concept of false negatives is expanded to include under-deterrence in the form of anticompetitive mergers that are proposed and slip through unchallenged (or with insufficient remedies). ${ }^{89}$ The determination of the standard that leads to optimal deterrence is complicated because these effects are difficult to predict in the absence of a history of different legal rules..$^{90}$

The $P N B$ (or some alternative) presumption applied to mergers would affect deterrence as well as interdiction of anticompetitive mergers. Because

\footnotetext{
${ }^{87}$ Olshausen, supra note 79 , at 318.

${ }^{88}$ At the same time, the presumption is not evidence. The moving party has the burden to establish the basic facts on which the presumed fact rests. FED. R. EvID. 301.

${ }^{89}$ For further discussion, see Jonathan B. Baker, The Case for Antitrust Enforcement, $17 \mathrm{~J}$. ECON. Persp., Fall 2003, at 27; Steven C. Salop, Merger Settlement and Enforcement Policy for Optimal Deterrence and Maximum Welfare, 81 Fordham L. Rev. 2647 (2013).

${ }^{90}$ Kaplow takes a creative Bayesian approach to the burden of proof that focuses on deterrence concerns. See Kaplow, supra note 59. Kaplow's model is formally premised on the assumption that the appellate court knows the frequencies of harmful and benign conduct that could occur under different legal rules. However, a key caveat is that these frequencies would be very difficult to estimate in the absence of changes in the legal standard over time or other experimentation.
} 
parties would be aware of the burden on them to rebut the presumption in advance, they would have the ability and incentive to account for it when deciding whether or not to propose a merger. Parties would also have the incentive to offer voluntary undertakings to remedy merger proposals that likely would be viewed as anticompetitive.

There are reasons to conclude that, absent a presumption, there is more likely to be under-deterrence than over-deterrence with respect to firms' merger decisions. First, and most generally, the decision-theory literature suggests that false positives as well as false negatives have an effect that tends to result in under-deterrence. Firms' motivation to comply with legal standards flows from their understanding that compliance will lead to a lower likelihood of sanctions than will non-compliance. Both false positives and false negatives reduce the advantages of compliance over non-compliance (false positives by increasing the likelihood that compliant firms will face sanctions and false negatives by reducing the likelihood that non-compliant firms will). ${ }^{91}$

Second, it seems reasonable to assume that the incentives to undertake anticompetitive mergers are large, absent antitrust constraints. ${ }^{92}$ Thus, mergers are unlike the Supreme Court's description of predatory pricing as conduct that is "rarely attempted and even more rarely successful." ${ }^{93}$ False negatives (i.e., under-deterrence) are a serious potential concern.

Third, while the agencies have the ability to attempt to block anticompetitive mergers in court - and gain a litigation advantage from the $P N B$ (or an updated) presumption when they do-the agencies nonetheless often are "gun shy" about litigating, leading them to accept remedies that fall short of optimally protecting consumers. It has been suggested that the agencies apply what might be called a "litigation discount," reflecting their fear of losing in court. ${ }^{94}$

\footnotetext{
${ }^{91}$ For further discussion, see Salop, supra note 89, at 2669 n.60 (If the probability of a false acquittal is $P_{a}$, the probability of a false conviction is $P_{c}$, and the sanction is a fine of $F$, then the expected sanction when the individual violates the rule is $\left(1-P_{a}\right) F$, while the expected sanction when the individual satisfies the rule is $P_{c} F$, so the incentive to satisfy the rule depends on the difference in expected sanctions $\left.\left(1-P_{a}-P_{c}\right) F\right)$, which is lower when $P_{a}$ is higher.) False acquittals are false positives and false convictions are false negatives.

${ }_{92}$ The only constraint would be large inefficiencies of managing the merged company. However, these potential inefficiencies could be resolved by managing the previously independent firms as separate divisions. The top managers of the divisions might have some incentives to continue to compete if their compensation were based solely on the profits of their respective divisions. But the corporate managers could resolve this difficulty by basing part of their compensation on the profits of the other, or the corporation as a whole or by placing an internal tax on their respective outputs.

${ }^{93}$ Brooke Grp. Ltd. v. Brown \& Williamson Tobacco Corp., 509 U.S. 209, 226 (1993) (citations omitted).

${ }^{94}$ For further analysis, see Salop, supra note 89; see also Lawrence M. Frankel, The Flawed Institutional Design of U.S. Merger Review: Stacking the Deck Against Enforcement, 2008 UtaH
} 
For these reasons, there are benefits to consumers from the courts applying a rebuttable presumption that certain mergers are anticompetitive. Of course, there are benefits to the courts as well from not having to re-litigate in every case the relevance to competitive effects analysis of market share and concentration. These presumptions obviously should be based on valid economic analysis, that is, proper economic presumptions. Similarly, there are benefits to maintaining up-to-date enforcement presumptions. ${ }^{95}$

\section{PNB'S EVOLUTIONARY PROSPECTS}

The $P N B$ presumption has been useful as it has evolved. Legal and enforcement presumptions are useful, so courts and agencies likely will be reluctant to give them up. However, this does not mean that the exact form of the presumption should be case in stone. ${ }^{96}$

In my view, it is neither necessary nor advisable at this time to reject anticompetitive presumptions based on high concentration and market shares. ${ }^{97}$ First, there are likely substantial administrative efficiencies to courts from formulating a presumption rather than just treating concentration and market shares as possibly relevant evidence. Otherwise, a court might need to review the entire economic literature in each case to determine relevance. It makes more sense for appellate courts to make this determination once and then to apply it to all cases in an appropriate way. Second, concentration levels and market shares at the high and low ends retain predictive power with respect to coordinated effects when the market is defined appropriately. ${ }^{98}$ Third, while market definition can be an imperfect exercise, the 2010 Merger Guidelines have improved the analytic framework. ${ }^{99}$

L. Rev. 159, 182-84 (2008). For the contrary view, see Joe Sims \& Michael McFalls, Negotiated Merger Remedies: How Well Do They Solve Competition Problems?, 69 Geo. Wash. L. Rev. 932 (2001).

95 This applies to both the anticompetitive presumption from high concentration and shares and the "safe harbor" presumptions from low concentration and shares. As discussed below, those safe harbors may sometimes represent rebuttable presumptions that the merger is unlikely to cause competitive concerns, not absolute safe harbors.

${ }^{96}$ Critics who propose to eliminate the $P N B$ presumption should specify exactly what legal standard would replace it. For example, one possible alternative legal standard would formally eliminate any presumption but treat the level and change in concentration as permissible evidence, but without specifying the weight or presuming its relevance to a particular case. A more extreme alternative would treat concentration evidence as legally impermissible, just as outsidemarket efficiencies and evidence on social debits and credits were held to be impermissible rebuttal factors in PNB. United States v. Phila. Nat'l Bank, 374 U.S. 321, 370-72 (1963).

${ }^{97}$ I similarly would not recommend eliminating the presumption that mergers in markets with low levels of concentration are unlikely to cause competitive concerns.

${ }^{98}$ See articles cited supra notes 45-46.

${ }^{99} \mathrm{~A}$ presumption based on market shares concentration requires a market to be defined. The 2010 Merger Guidelines stress that the market definition exercise is subject to inherent imperfections and uncertainties. See 2010 Merger Guidelines, supra note 8, § 4 ("The Agencies imple- 
However, stating that an anticompetitive presumption has benefits does not mean that the exact form of the $P N B$ presumption adopted in 1963 should still be followed. For example, the HHI is not the best proxy for unilateral effects concerns. And there is a growing body of empirical evidence that suggests that merger enforcement has been too lenient in preventing post-merger price increases, perhaps because effective remedies are hard to craft. ${ }^{100}$ Thus, as merger analysis and economic evidence evolve, so should the presumptions.

The 2010 Merger Guidelines have suggested several candidates that might supplement or even replace the current presumptions. Some of the candidates apply to both unilateral effects and coordinated effects concerns, while others apply only to one of the theories. The role of these and other candidates should be considered and debated. In this way, new presumptions may supplement the use of concentration and market shares, and possibly may replace them over time, at least in some circumstances. In my view, they should be adopted as supplementary presumptions along with the HHI, and should trump the HHI in certain circumstances.

\section{A. Gross Upward Pricing Pressure Indices (GUPPIs)}

The 1992 Merger Guidelines could be read to suggest that enforcement would only occur if the combined market share of the merging parties exceeded 35 percent. ${ }^{101}$ The 2010 Merger Guidelines made an important evolutionary change by introducing a new way to score unilateral effects concerns that has come to be called the GUPPI. ${ }^{102}$ The GUPPI depends on the closeness of competition between the merging firms, the price-cost margins of the firms, and their relative prices. ${ }^{103}$ The GUPPI can be used as evidence at trial or as the basis of either anticompetitive or "no harm" rebuttable presumptions.

ment these principles of market definition flexibly when evaluating different possible candidate markets.").

${ }^{100}$ For some recent empirical studies, see John Kwoka, Mergers, Merger Control and Remedies: A Retrospective Analysis of U.S. Policy (2015) and the references cited therein; see also Orley Ashenfelter, Daniel S. Hosken \& Matthew Weinberg, Did Robert Bork Understate the Competitive Impact of Mergers? Evidence from Consummated Mergers, 57 J.L. \& Econ. 67 (2014); Orley Ashenfelter et al., Retrospective Analysis of Hospital Mergers, 18 InT'L J. ECon. Bus. 5 (2011); Orley Ashenfelter \& Daniel S. Hosken, The Effect of Mergers on Consumer Prices: Evidence from Five Selected Case Studies, 53 J.L. \& Econ. 417 (2010); Daniel Hosken, Luke M. Olson \& Loren K. Smith, Do Retail Mergers Affect Competition? Evidence from Grocery Retailing (FTC Working Paper No. 313, 2012).

1011992 Merger Guidelines, supra note 22, § 2.211.

1022010 Merger Guidelines, supra note 8, $\S 6.1$. For further discussion of the role of the GUPPI, see Carl Shapiro, The 2010 Horizontal Merger Guidelines: From Hedgehog to Fox in Forty Years, 77 AnTiTRust L.J. 701 (2010) [hereinafter Shapiro, Hedgehog].

103 The simple GUPPI for merging firm- 1 is given by, GUPPI $1=\mathrm{DR}_{12} \cdot \mathrm{m}_{2} \cdot \mathrm{P}_{2} / \mathrm{P}_{1}$, where $\mathrm{DR}_{12}$ is the diversion ratio from firm-1 to merging firm-2, $\mathrm{m}_{2}$ is the percentage price-variable cost margin of firm- 2 , and $\mathrm{P}_{2} / \mathrm{P}_{1}$ is the ratio of their prices. The simple GUPPI for merging firm- 2 is defined similarly. For further details, see Serge Moresi, The Use of Upward Price Pressure 
The 2010 Merger Guidelines do not adopt a rebuttable anticompetitive presumption based on high values of the GUPPI score. This could have reflected a policy decision based on the fact that the use of the GUPPI still was new to much of the merger bar and the courts. As the agencies and the courts become more experienced with measures of upward pricing pressure like the GUPPI, it is a good candidate for a rebuttable presumption. The Guidelines suggest the existence of a GUPPI rebuttable no-harm presumption ("quasi-safe harbor") but do not specify a particular threshold. They merely state that "[i]f the value of diverted sales is proportionately small, significant unilateral price effects are unlikely." 104

The use of the GUPPI rebuttable presumptions should satisfy critics of the $P N B$ presumptions based in market concentration. First, unlike market definition and concentration, the GUPPI is based directly on the pricing incentives of the merging firms. Second, it does not require market definition so it is not subject to the criticism that market definition is an imperfect or flawed procedure. Third, while it does not require a market to be defined, the GUPPI methodology bears a close affinity to the underlying foundation of market definition. In fact, the diversion ratio is closely related to the ratio of the cross-elasticity of demand to the own-elasticity of demand. Moreover, if the GUPPIs of the competing products of the merging firms exceed 10 percent, then the application of the hypothetical monopolist test often would imply that those products by themselves would comprise a two-firm relevant product market. ${ }^{105}$ In this limited sense, the merger could be interpreted as a potential merger to monopoly in a market comprised solely of the merging products. This 10 percent level also is a natural benchmark for setting the anticompeti-

Indices in Merger Analysis, ANTITRust Source, Feb. 2010, at 6, www.americanbar.org/content/ dam/aba/publishing/antitrust_source/Feb10_Moresi2_25f.authcheckdam.pdf; Steven Salop, Serge Moresi \& John Woodbury, Scoring Unilateral Effects with the GUPPI: The Approach of the New Horizontal Merger Guidelines (Aug. 31, 2010), www.crai.com/uploadedFiles/Publica tions/CRA_Competition_Memo_Comments_on_the_GUPPI_0211.pdf.

${ }^{104}$ The value of diverted sales in such proportional terms is the definition of the GUPPI. In a speech while he was Deputy AAG, Carl Shapiro also specified a GUPPI quasi-safe harbor of $5 \%$. See Carl Shapiro, Deputy Assistant Att'y Gen., Antitrust Div., U.S. Dep't. of Justice, Remarks to the ABA Section of Antitrust Law Fall Forum, Update from the Antitrust Division (Nov. 18, 2010), available at www.justice.gov/atr/public/speeches/264295.pdf. As a speech by the Deputy AAG, this statement appeared to reflect DOJ policy.

105 If all the GUPPIs exceed $10 \%$ and the pass-through rate is $50 \%$, then a hypothetical monopolist would have the incentive to raise both prices by at least 5\%, the standard SSNIP ("small and significant non-transitory increase in price") used for the test. For more details, see Moresi, supra note 103, at 7. However, the Merger Guidelines nonetheless might not define a market as comprising solely those two merging products if the products sold by any other firms were closer substitutes for either of the products of the merging firms. 2010 Merger Guidelines, supra note 8, $\S 4.1 .1$ (example 6). 
tive presumption. In addition, the diversion ratios themselves can be related to the increase in the HHI when diversion is proportional to market share. ${ }^{106}$

The use of the GUPPI and the HHI could create conflicting presumptions. For example, suppose that the GUPPIs between the merging parties are very low, but the defined market is highly concentrated and the increase in the HHI is sufficiently large. ${ }^{107}$ The language of the 2010 Merger Guidelines suggests that the HHI presumption will yield to the GUPPIs for unilateral effects concerns. The Merger Guidelines state:

Diagnosing unilateral price effects based on the value of diverted sales need not rely on market definition or the calculation of market shares and concentration. The Agencies rely much more on the value of diverted sales than on the level of the HHI for diagnosing unilateral price effects in markets with differentiated products. ${ }^{108}$

In my own view, the GUPPI forms a stronger basis for unilateral effects rebuttable presumptions than does the HHI. The GUPPI score flows directly from the economic analysis of pricing incentives. If a firm's marginal costs of increasing output are raised, it will have the incentive to raise its price. A merger of a firm that produces substitute products raises the "opportunity cost" of increasing output because increasing output comes at the expense of the profits of the merged firm. As a result, multi-product firms selling substitute products, or merged firms doing the same, have the incentive to charge higher prices. ${ }^{109}$

In contrast, market shares and concentration generally have a more attenuated relationship to unilateral pricing incentives. For example, even if the market in Staples ${ }^{110}$ had been defined more broadly by a less formal test as the retail sales of office consumables by all retailers, not just office superstores, the economic analysis of pricing incentives would have been the same. Similarly, the "natural experiment" geographic pricing comparisons in Staples

\footnotetext{
106 The unweighted average of the two diversion ratios in these conditions is approximately equal to the combined market share of the merging firms plus the increase in the HHI. In symbols, $1 / 2\left(D_{1}+D_{2}\right)=S_{1}+S_{2}+d H H I$, where $D_{1}$ and $D_{2}$ are the diversion ratios of the merging firms, $S_{1}$ and $S_{2}$ are their pre-merger market shares dHHI $=2 \times S_{1} \times S_{2}$. Shapiro, Hedgehog, supra note 102, at 721; Robert D. Willig, Merger Analysis, Industrial Organization Theory, and Merger Guidelines, 1991 Brookings Papers on Econ. Activity: MicroeconoMICs 281 (1991).

1072010 Merger Guidelines, supra note 8, § 5.3.

${ }^{108} I d$. $§ 6.1$ (emphases added).

${ }^{109}$ For empirical applications to multi-product firms, see Aviv Nevo, Measuring Market Power in the Ready-to-Eat Cereal Industry, 69 EconOMETRICA 307, 332-33 (2001); Raphael Thomadsen, The Effect of Ownership Structure on Prices in Geographically Differentiated Industries, 36 RAND J. ECON. 908 (2005).

${ }^{110}$ FTC v. Staples, Inc., 970 F. Supp. 1066 (D.D.C. 1997).
} 
would have been just as salient if Judge Hogan had defined the relevant market broadly. ${ }^{111}$

The FTC recently addressed the role of the GUPPI in the context of accepting a settlement in Dollar Tree's acquisition of Family Dollar Stores. The Commission statement (representing four of the Commissioners) expressed support for using the GUPPI as one factor in merger analysis while also suggesting certain limitations. The statement explained that it used the GUPPI as a screen and as relevant evidence. ${ }^{112}$ In his partially concurring and partially dissenting statement, Commissioner Wright also embraced the use of the GUPPI. ${ }^{113}$ Neither the Commission majority nor Commissioner Wright proposed an anticompetitive presumption for high GUPPI scores. ${ }^{114}$

However, there was significant disagreement over the proper treatment of low GUPPIs. The Commission majority rejected the adoption of a GUPPI safe harbor, which was proposed in the dissenting statement of Commissioner Wright. ${ }^{115}$ The Commission appeared to be concerned about difficulties in reliably estimating diversion ratios. However, even if the GUPPI could be calculated correctly, the Commission majority highlighted a further caveat. Citing Farrell and Shapiro's hypothetical of price competition between homogeneous product duopolists driving price down to marginal cost, the Commission noted that "intense competition between merging firms may cause margins to be very low, which could produce a low GUPPI even in the presence of very high diversion ratios. Such conditions could produce a false negative implying that the merger [of the duopolists] is not likely to harm competition when in fact it is." 116

\footnotetext{
111 While this conflict in principle could be resolved simply by defining the market narrowly, that approach would improperly focus the inquiry on the possibly imperfect and potentially flawed process of market definition rather than directly on competitive effects. At the same time, the construction of the GUPPI captures the issue of substitution between the merging parties using the same basic economic tools as used for market definition, so a focus on the GUPPI would not represent an outright rejection of the concepts of own-elasticity and cross-elasticity that form the basis of market definition analysis.

${ }^{112}$ Statement of the Federal Trade Commission, Dollar Tree, Inc. and Family Dollar Stores, Inc., FTC File No. 141-0207 (July 13, 2015) [hereinafter Commission Statement], available at www.ftc.gov/system/files/documents/public_statements/681901/150714dollarstoresstate ment.pdf.

${ }^{113}$ Statement of Commissioner Joshua D. Wright Dissenting in Part and Concurring in Part, Dollar Tree, Inc. and Family Dollar Stores, Inc., FTC File No. 141-0207 (July 13, 2015) [hereinafter Wright Dissent], available at www.ftc.gov/system/files/documents/public_statements/ 681781/150713dollartree-jdwstmt.pdf.

114 Commission Statement, supra note 112, at 3; Wright Dissent, supra note 113, at 8.

115 Wright Dissent, supra note 113, at 3.

${ }^{116}$ Commission Statement, supra note 112, at 3 (citing Joseph Farrell \& Carl Shapiro, Upward Pricing Pressure and Critical Loss Analysis: Response, CPI Antitrust J., Feb. 2010, at 1, 6-7 \& n.15; Joseph Farrell \& Carl Shapiro, Antitrust Evaluation of Horizontal Mergers: An Economic Alternative to Market Definition, 10 B.E. J. Theoretical Econ.: Policies \& PersP., Vol. 10, No. 1, Art. 9, at 1, 13-14 (2010).
} 
Farrell and Shapiro's hypothetical example provides a rationale for rejecting a "conclusive" (i.e., unrebuttable) safe harbor, which Commissioner Wright appears to have proposed. ${ }^{117}$ However, a "rebuttable" no-harm presumption would be consistent with the hypothetical. In Farrell and Shapiro's example, the diversion ratio is very high while the margin is very low. Thus, the rebuttal could evaluate whether this set of facts is responsible for the observed low GUPPI. If the cause of the low GUPPI instead is a low diversion ratio (and if the relevant GUPPI is reliably estimated), then the overlap could obtain safe harbor protection. This type of rebuttable presumption is worthy of further consideration.

The GUPPI is applied to unilateral concerns in the Merger Guidelines. However, the "uniform" GUPPI, which measures the incentives of a group of firms to raise their prices by a uniform amount, has a potential role in analyzing coordinated effects concerns. Suppose that a group of firms were attempting to coordinate by uniform percentage price increases above the noncoordinated equilibrium price level. If the uniform GUPPI rises substantially from a merger, coordinated effects concerns would be higher. This approach eventually might form a basis for an anticompetitive presumption applied to coordinated effects concerns. ${ }^{118}$

\section{B. High Margins}

The 2010 Merger Guidelines observe that high margins do not imply that the firms are violating the antitrust laws in the pre-merger world. ${ }^{119}$ However, high margins do raise concerns about proposed mergers, ceteris paribus. If the merging firms and the other major firms all have high price-variable cost margins, that fact might be used to trigger an anticompetitive enforcement presumption for proposed mergers.

High margins can signal both unilateral effects and coordinated effects concerns. The margin is one component of the GUPPI used to evaluate unilateral effects. High margins also can signal the existence of pre-merger interaction. The 2010 Merger Guidelines recognize these dual concerns from high margins. As stated in the Merger Guidelines, "If a firm sets price well above incremental cost, that normally indicates either that the firm believes its customers are not highly sensitive to price (not in itself of antitrust concern) or that the firm and its rivals are engaged in coordinated interaction." 20

\footnotetext{
117 Wright Dissent, supra note 113, at 3-5.

${ }^{118}$ For more details, see Serge Moresi et al., cGUPPI: Scoring Incentives to Engage in Parallel Accommodating Conduct (Geo. L. Faculty Publications \& Other Works, Paper No. 1501, Aug. 14, 2015), scholarship.law.georgetown.edu/facpub/1501.

1192010 Merger Guidelines, supra note 8, § 4.1.3 n.6.

${ }^{120} I d$. $\S 2.2 .1$ (internal references omitted). If consumers are less price sensitive, that would lead to higher GUPPIs.
} 
Any presumption would be rebuttable, however, because high margins may have other causes. First, a firm could have a high margin if it has lower variable costs than its rivals but has strictly limited capacity. Second, margins may be measured incorrectly. The relevant measure is not the "average" price-cost margin as calculated over the entire range of output. Instead, it is the "local" price-cost margin measured in the narrow vicinity around the current output level. These two measures can be significantly different. For example, if all firms have low variable costs that rapidly rise as full capacity is reached, and the firms are operating close to that full capacity, their "average" price-cost margins will be high, but their "local" price-cost margins will be low. ${ }^{121}$

Third, a firm's sale of multiple differentiated products may also affect its pre-merger margins. ${ }^{122}$ If a firm's products are substitutes, that fact will lead the firm to set a higher price (and thus achieve a higher margin) because it recognizes that some substitution will flow to its other products. If the firm's other products are complements, the firm will have the incentive to charge a lower price, which will reduce its margin. ${ }^{123}$ This factor would need to be taken into account if a presumption were based on the margin.

\section{Acquisition of a Maverick}

The 2010 Merger Guidelines also suggest an anticompetitive enforcement presumption for a merger that involves the acquisition of a maverick firm. The Guidelines state that "[a]n acquisition eliminating a maverick firm (see Section 2.1.5) in a market vulnerable to coordinated conduct is likely to cause adverse coordinated effects." 124 This presumption generally would strengthen the concentration-based anticompetitive presumption rather than replace it. ${ }^{125}$ For example, a maverick might have the largest effects when the market is concentrated.

\footnotetext{
${ }^{121}$ The parties then could show that the "average" margin statistic provides an inaccurate measure, just as market shares and concentration might provide inaccurate measures or signals. The measurement of price-cost margins also can raise other issues. For example, when firms are growing, the appropriate margin calculation may count a fraction of capital expansion costs as variable. This fraction will depend on the interest rate and the depreciation rate.

122 The statement quoted from the Guidelines applied more directly to single product firms.

${ }^{123}$ When demand is dynamic, future sales may be complements. See, e.g., Serge X. Moresi \& Steven C. Salop, The Sirius/XM Satellite Radio Merger (2008), in The Antitrust Revolution: Economics, Competition and Policy 92 (John E. Kwoka \& Lawrence J. White eds., 6th ed. 2013).

1242010 Merger Guidelines, supra note 8, § 7.1; see also id. § 2.1.5. For an earlier statement, see Jonathan B. Baker \& Carl Shapiro, Reinvigorating Horizontal Merger Enforcement, in How the Chicago School Overshot the Mark: The Effect of Conservative Economic Analysis ON U.S. ANTItrust 235, 258-66 (Robert Pitofsky ed., 2008).

${ }^{125}$ See Baker \& Shapiro, supra note 124, at 261-63.
} 
However, there could be dueling presumptions with respect to the acquisition of a maverick. The acquisition of a maverick might create an anticompetitive presumption in moderately concentrated markets, instead of simply strengthening the presumption in highly concentrated markets. ${ }^{126}$ The acquisition of a maverick also in principle appropriately might be used successfully to rebut the no-harm presumption in an unconcentrated market close to the moderately concentrated threshold. These are issues for further analysis and debate.

\section{History of Collusion}

The 2010 Merger Guidelines also apply an anticompetitive enforcement presumption to markets in which there is a history of successful collusion. ${ }^{127}$ As highly concentrated markets are more vulnerable to collusion, this history generally would strengthen the concentration-based anticompetitive presumption rather than replace it. However, there could be dueling presumptions here, as well. Suppose that there is evidence of previous collusion, but the post-merger market is unconcentrated and falls into the HHI safe harbor. ${ }^{128}$ The Guidelines language quoted earlier suggests that the history of collusion could trump the concentration evidence. This approach would comport with antitrust experience. While collusion is less likely in an unconcentrated market, history has shown that successful cartels may have a large number of participants. ${ }^{129}$ Thus, this approach makes economic sense.

Each of these factors is directly related to the incentives or ability to engage in post-merger conduct that harms consumers. They flow from practical considerations and economic analysis more directly than does the level of market concentration. Thus, they are attractive candidates for evolution in the formulation of anticompetitive presumptions to be used in enforcement and ultimately by the courts. I would recommend that they be added as supplementary sources of presumptions.

${ }^{126}$ For further details, see id.

1272010 Merger Guidelines, supra note 8, § 7.2. Failed attempts to collude do not create an anticompetitive presumption.

${ }^{128} I d$. $\S 5.3$ (delineating safe harbor for unconcentrated markets).

${ }^{129}$ See, e.g., William J. Kolasky, Coordinated Effects in Merger Review: From Dead Frenchmen to Beautiful Minds and Mavericks, Address Before ABA Section of Antitrust Law Spring Meeting (Apr. 24, 2002), available at www.usdoj.gov/atr/public/speeches/11050.htm. 


\section{E. The Government's Burden of Proof}

The discussion of presumptions and the associated burden of proof also raises the issue of whether the FTC and DOJ should face a lower burden of proof in merger cases than do private plaintiffs. One rationale for requiring a lower burden of proof is that the FTC and DOJ both are expert antitrust agencies with vast experience in analyzing numerous mergers every year. Another is that the agencies have a mandate only to bring cases that are in the public interest. ${ }^{130}$ In contrast, private plaintiffs might have the incentive to try to enjoin mergers that would increase competition or to obtain large financial settlements. ${ }^{131}$ While the FTC already is assigned a somewhat lower burden of proof because of its expertise, that same rationale might be applied to the DOJ as well. In this regard, it is not clear why the appropriate resolution to the agencies' uneven burdens of proof is to suggest that the FTC's burden be raised, rather than that the DOJ's be lowered. ${ }^{132}$

\section{CONCLUSION}

All in all, the 1963 formulation of the $P N B$ structural presumption was a forward-looking analytic approach to antitrust jurisprudence. This use of legal and enforcement presumptions based on economic presumptions arising from economic theory and evidence and judicial experience has now spread across all of antitrust. The $P N B$ presumption for mergers also has evolved as economic theory and evidence have advanced. Looking forward, merger presumptions should be neither abandoned nor set in stone; instead, they should be permitted to continue to evolve, based on new or additional economic factors besides market shares and concentration.

${ }^{130}$ For a general discussion, see Daniel Crane, Antitrust Antifederalism, 96 CALIF. L. Rev. 1, 52-53 (2008).

${ }^{131}$ At the same time, competitors' interests often do correspond to the interests of consumers, as for example, when the merger would permit the merged firm to engage in anticompetitive foreclosure.

132 See, e.g., Antitrust Modernization Comm'n, Report and Recommendation 141 (2007), available at govinfo.library.unt.edu/amc/report_recommendation/toc.htm; see also АM. Bar Ass'n, Section of Antitrust Law, Presidential Transition Report: The State of ANTITRUSt ENFORCEMENT 2012, at 9-10 (2013). 